Standard Reference Materials:

\title{
SELECTION OF
}

\section{DIFFERENTIAL THERMAL ANALYSIS}

\author{
TEMPERATURE STANDARDS
}

THROUGH A COOPERATIVE STUDY

\section{ISRM 758, 759, 760}

U.S. EPARTMENT OF COMMERCE National Bureau of Standards

\begin{tabular}{c}
$Q C$ \\
100 \\
.457 \\
$n 0.260 .40$ \\
1972 \\
$c .2$ \\
\hline
\end{tabular}




\section{NATIONAL BUREAU OF STANDARDS}

The National Bureau of Standards ${ }^{1}$ was established by an act of Congress March 3, 1901. The Bureau's overall goal is to strengthen and advance the Nation's science and technology and facilitate their effective application for public benefit. To this end, the Bureau conducts research and provides: (1) a basis for the Nation's physical measurement system, (2) scientific and technological services for industry and government, (3) a technical basis for equity in trade, and (4) technical services to promote public safety. The Bureau consists of the Institute for Basic Standards, the Institute for Materials Research, the Institute for Applied Technology, the Center for Computer Sciences and Technology, and the Office for Information Programs.

THE INSTITUTE FOR BASIC STANDARDS provides the central basis within the United States of a complete and consistent system of physical measurement; coordinates that system with measurement systems of other nations; and furnishes essential services leading to accurate and uniform physical measurements throughout the Nation's scientific community, industry, and commerce. The Institute consists of a Center for Radiation Research, an Office of Measurement Services and the following divisions:

Applied Mathematics-Electricity-Heat-Mechanics-Optical Physics-Linac Radiation ${ }^{2}$-Nuclear Radiation ${ }^{2}$ - Applied Radiation ${ }^{2}$ - Quantum Electronics ${ }^{3}$ Electromagnetics ${ }^{3}$ - Time and Frequency ${ }^{3}$ - Laboratory Astrophysics ${ }^{3}$ - Cryogenics ${ }^{3}$.

THE INSTITUTE FOR MATERIALS RESEARCH conducts materials research leading to improved methods of measurement, standards, and data on the properties of well-characterized materials needed by industry, commerce, educational institutions, and Government; provides advisory and research services to other Government agencies; and develops, produces, and distributes standard reference materials. The Institute consists of the Office of Standard Reference Materials and the following divisions:

Analytical Chemistry-Polymers-Metallurgy-Inorganic Materials-Reactor Radiation-Physical Chemistry.

THE INSTITUTE FOR APPLIED TECHNOLOGY provides technical services to promote the use of available technology and to facilitate technological innovation in industry and Government; cooperates with public and private organizations leading to the development of technological standards (including mandatory safety standards), codes and methods of test; and provides technical advice and services to Government agencies upon request. The Institute also monitors NBS engineering standards activities and provides liaison between NBS and national and international engineering standards bodies. The Institute consists of the following divisions and offices:

Engineering Standards Services-Weights and Measures-Invention and Innovation-Product Evaluation Technology-Building Research-Electronic Technology-Technical Analysis-Measurement Engineering-Office of Fire Programs.

THE CENTER FOR COMPUTER SCIENCES AND TECHNOLOGY conducts research and provides technical services designed to aid Government agencies in improving cost effectiveness in the conduct of their programs through the selection, acquisition, and effective utilization of automatic data processing equipment; and serves as the principal focus within the executive branch for the development of Federal standards for automatic data processing equipment, techniques, and computer languages. The Center consists of the following offices and divisions:

Information Processing Standards-Computer Information-Computer Services -Systems Development-Information Processing Technology.

THE OFFICE FOR INFORMATION PROGRAMS promotes optimum dissemination and accessibility of scientific information generated within NBS and other agencies of the Federal Government; promotes the development of the National Standard Reference Data System and a system of information analysis centers dealing with the broader aspects of the National Measurement System; provides appropriate services to ensure that the NBS staff has optimum accessibility to the scientific information of the world, and directs the public information activities of the Bureau. The Office consists of the following organizational units:

Office of Standard Reference Data-Office of Technical Information and Publications-Library-Office of International Relations.

\footnotetext{
1 Headquarters and Laboratories at Gaithersburg, Maryland, unless otherwise noted; mailing address Washing-
ton, D.C. 20234 .

${ }^{3}$ Located at Boulder, Colorado 80302.
} 
D) 100 Standard Reference Materials:

\section{7
$260-40$ 9792 \\ Through a Cooperative Study \\ (SRM 758, 759, 760)}

H. G. McAdie

Ontario Research Foundation

Toronto, Ontario, Canada

Paul D. Garn

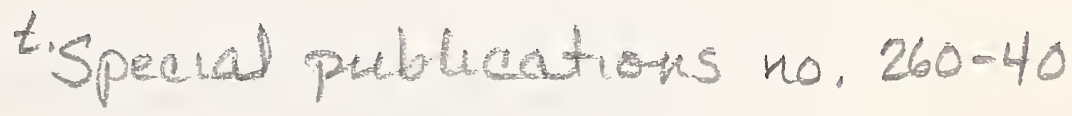

The University of Akron

Akron, Ohio 44384

and

Oscar Menis

Analytical.Chemistry Division

Institute for Materials Research

U.S.National Bureau of Standards

$\because$ Washington, D.C. 20234

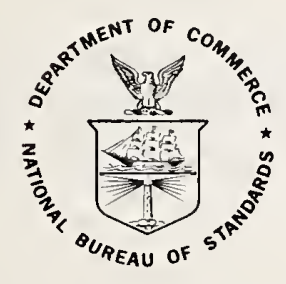

U.S. DEPARTMENT OF COMMERCE, Peter G. Peterson, Secretary

NATIONAL BUREAU OF STANDARDS, Lawrence M. Kushner, Acting Director,

Issued August 1972 
Library of Congress Catalog Card Number: 72-600191

National Bureau of Standards Special Publication 260-40

Nat. Bur. Stand. (U.S.), Spec, Publ. 260-40, 71 pages (Aug. 1972)

CODEN: XNBSAV

For sale by the Superintendent of Documents, U.S. Government Printing Office, Washington, D.C. 20402 (Order by SD Catalog No. C13.10:260-40). Price 65 cents. 
Standard Reference Materials (SRM's) as defined by the National Bureau of Standards are "we11-characterized materials, produced in quantity, that calibrate a measurement system to assure compatibility of measurement in the nation." SRM's are widely used as primary standards in many diverse fields in science, industry, and technology, both within the United States and throughout the world. In many industries traceability of their quality control process to the national measurement system is carried out through the mechanism and use of SRM's. For many of the nation's scientists and technologists it is therefore of more than passing interest to know the details of the measurements made at NBS in arriving at the certified values of the SRM's produced. An NBS series of papers, of which this publication is a member, called the NBS Special Publication - 260 Series is reserved for this purpose.

This 260 Series is dedicated to the dissemination of information on all phases of the preparation, measurement, and certification of NBS-SRM's. In general, much more detail will be found in these papers than is generally allowed, or desirable, in scientific journal articles. This enables the user to assess the validity and accuracy of the measurement processes employed, to judge the statistical analysis, and to learn details of techniques and methods utilized for work entailing the greatest care and accuracy. It is also hoped that these papers will provide sufficient additional information not found on the certificate so that new applications in diverse fields not foreseen at the time the SRM was originally issued will be sought and found.

Inquiries concerning the technical content of this paper should be directed to the author(s). Other questions concerned with the availability, delivery, price, and so forth will receive prompt attention from:

Office of Standard Reference Materials

National Bureau of Standards

Washington, D.C. 20234

J. Pau1 Ca1i, Chief

Office of Standard Reference Materials 

NBS Spec. Publ. 260, Catalog of Standard Reference Materials, July 1970. 75 cents.* (Supersedes NBS Misc. Publ. 260, January 1968 and NBS Misc. Publ. 24l, March 1962.)

NBS Misc. Publ. 260-1, Standard Reference Materials: Preparation of NBS White Cast Iron Spectrochemical Standards, June 1964. 30 cents.*

NBS Misc. Publ. 260-2, Standard Reference Materials: Preparation of NBS Copper-Base Spectrochemical Standards, October 1964. 35 cents.*

NBS Misc. Publ. 260-3, Standard Reference Materials: Metallographic Characterization of an NBS Spectrometric Low-Alloy Steel Standard, October 1964. 20 cents.* (Out of print).

NBS Misc. Publ. 260-4, Standard Reference Materials: Sources of Information on Standard Reference Materials, February 1965. 20 cents. ${ }^{*}$ (Out of print).

NBS Misc. Publ. 260-5, Standard Reference Materials: Accuracy of Solution X-Ray Spectrometric Analysis of Copper-Base Alloys, March I965. 25 cents.* (Out of print).

NBS Misc. Publ. 260-6, Standard Reference Materials: Methods for the Chemical Analysis of White Cast Iron Standards, July 1965. 4.5 cents. *

NBS Misc. Publ. 260-7, Standard Reference Materials: Methods for the Chemical Analysis of NBS Copper-Base Spectrochemical Standards, October 1965.60 cents. *

NBS Misc. Publ. 260-8, Standard Reference Materials: Analysis of Uranium Concentrates at the National Bureau of Standards, December 1965.60 cents. * (Out of print).

NBS Misc. Publ. 260-9, Standard Reference Materials: Half Lives of Materials Used in the Preparation of Standard Reference Materials of Nineteen Radioactive Nuclides Issued by the National Bureau of Standards, November 1965. 15 cents. *

NBS Misc. Publ. 260-I0, Standard Reference Materials: Homogeneity Characterization on NBS Spectrometric Standards II: Cartridge Brass and Low-Alloy Steel, December 1965. 30 cents.*

NBS Misc. Publ. 260-11, Standard Reference Materials: Viscosity of a Standard Lead-Silica Glass, November 1966. 25 cents.*
NBS Misc. Publ. 260-12, Standard Reference Materials: Homogeneity Characterization of NBS Spectrometric Standards III: White Cast Iron and Stainless Steel Powder Compact, September 1966. 20 cents.*

NBS Misc. Publ. 260-13, Standard Reference Materials: Mossbauer Spectroscopy Standard for the Chemieal Shift of Iron Compounds, July 1967.40 cents. *

NBS Misc. Publ. 260-14, Standard Reference Materials: Determination of Oxygen in Ferrous Materials - SRM 1090, 1091, and I092, September 1966.30 cents. *

NBS Misc. Publ. 260-15, Standard Reference Materials: Recommended Method of Use of Standard Light-Sensitive Paper for Calibrating Carbon Arcs Used in Testing Textiles for Colorfastness to Light, June 1967. 20 cents.* NBS Spec. Publ. 260-16, Standard Reference Materials: Homogeneity Characterization of NBS Spectrometric Standards IV: Preparation and Microprobe Characterization of W-20\% Mo Alloy Fabricated by Powder Metallurgical Methods, January 1969. 35 cents. *

NBS Spec. Publ. 260-17, Standard Reference Materials: Boric Acid; Isotopic and Assay Standard Reference Materials, February 1970.65 cents.*

NBS Spec. Publ. 260-I8, Standard Reference Materials: Calibration of NBS Secondary Standard Magnetic Tape (Computer Amplitude Reference) Using the Reference Tape Amplitude Measurement "Process A", November 1969.50 cents."

NBS Spec. Publ. 260-19, Standard Reference Materials: Analysis of Interlaboratory Meas. urements on the Vapor Pressure of Gold (Certification of Standard Reference Material 745), January 1970.30 cents.*

NBS Spec. Publ. 260-20, Standard Reference Materials: Preparation and Analysis of Trace Element Glass Standards. (In preparation)

NBS Spec. Publ. 260-21, Standard Reference Materials: Analysis of Interlaboratory Measurements on the Vapor Pressures of Cadmium and Silver, January 1971. 35 cents.*

NBS Spec. Publ. 260-22, Standard Reference Materials: Homogeneity Characterization of Fe-3Si Alloy, February 1971. 35 cents.*

NBS Spec. Publ. 260-23, Standard Reference Materials: Viscosity of a Standard Borosilicate Glass, December 1970. 25 cents.* 
NBS Spec. Publ. 260-24, Standard Reference Materials: Comparison of Redox Standards, January 1972. \$I.*

NBS Spec. Publ. 260-25, Standard Reference Materials: A Standard Reference Material Containing Nominally Four Percent Austenite, February 1971. 30 cents.*

NBS Spec. Publ. 260-26, Standard Reference Materials: National Bureau of StandardsU.S. Steel Corporation Joint Program for Determining Oxygen and Nitrogen in Steel, February 1971.50 cents.*

NBS Spec. Publ. 260-27, Standard Reference Materials: Uranium Isotopic Standard Reference Materials, A pril 1971. \$1.25.*

NBS Spec. Publ. 260-28, Standard Reference Materials: Preparation and Evaluation of SRM's 481 and 482 Gold-Silver and GoldCopper Alloys for Microanalysis, August 1971.\$1.*

NBS Spec. Publ. 260-29, Standard Reference Materials: Calibration of NBS Secondary Standard Magnetic Tape (Computer Amplitude Reference) Using the Reference Tape Amplitudc Measurement "Process A-Model 2", June 1971.60 cents. *

NBS Spec. Publ. 260-30, Standard Reference Materials: Standard Samples Issued in the USSR (A Translation from the Russian), June 197I. \$I.*

NBS Spec. Publ. 260-31, Standard Reference Materials: Thermal Conductivity of Electrolytic Iron SRM 734 from 4 to $300 \mathrm{~K}$, November 1971.35 cents.*

NBS Spec. Publ. 260-32, Standard Reference Materials: The Cooperative Study of Temperature Scale Standards for DTA by ICTA and NBS. (In preparation)
NBS Spec. Publ. 260-33, Standard Reference Materials: Comparison of Original and Supplemental SRM 705, Narrow Molecular Weight Distribution Polystyrene, H. L. Wagner,.May 1972. 35 cents.*

NBS Spec. Publ. 260-34, Standard Reference Materials: Thermoelectric Voltage, April 1972.40 cents. *

NBS Spec. Publ. 260-35, Standard Reference Materials: Thermal Conductivity of Austenitic Stainless Steel, SRM 735 from 5 to $280 \mathrm{~K}$, April 1972. 35 cents. *

NBS Spec. Publ. 260-36, Standard Reference Materials: A Referee Method for the Determination of Calcium in Serum. SRM 736, May 1972. $\$ 1.25 . *$

NBS Spec. Publ. 260-37, Standard Reference Materials: Methods of Analysis of NBS Clay Standards, June 1972. 75 cents.*

NBS Spec. Publ. 260-38, Standard Reference Materials: Preparation and Calibration of Standards of Spectral Specular Reflectance, May 1972.60 cents.*

NBS Spec. Publ. 260-39, Standard Reference Materials: The Eddy Current Decay Method for Resistivity Characterization of HighPurity Metals, May 1972.55 cents.*

NBS Spec. Publ. 260-40, Standard Reference Materials: Selection of Thermal Analysis Temperature Standards Through a Cooperative Study (SRM 758, 759, 760). (In preparation)

NBS Spec. Publ. 260-4l, Standard Reference Materials: Use of Standard Light-Sensitive Paper for Calibrating Carbon Arcs used in Testing Textiles for Colorfastness to Light. (In preparation)

*Send order with remittance to: Superintendent of Documents, U.S. Government Printing Office, Washington, D.C. 20402. Remittance from foreign countries should include an additional one-fourth of the purchase price for postage. 
CONTENTS

PAGE

I. INTRODUCTION . . . . . . . . . . . . . . 2

II. THE SECOND INTERNATIONAL TEST PROGRAM. . . . . 3

II . MATERIALS

A. Systems Criteria . . . . . . . . . 3

B. Transition Criteria. . . . . . . . . 4

C. Selected Materials . . . . . . . . 5

IV. INVESTIGATORS AND EQUIPMENT. . . . . . . . . . 6

V. DATA HANDLING. . . . . . . . . . . . . . 7

A. Data Preparation . . . . . . . . . 7

B. Data Processing. . . . . . . . . . . 8

VI. RESULTS - TEMPERATURE DATA . . . . . . . . 10

A. Tests for Systematic Bias. . . . . . . . 10

B. Mean Temperature Results . . . . . . . 12

C. Influence of Experimental Parameters . . 15

1. Effect of Thermocouple Calibration . . 15

2. T-Thermocouple Placement... . . 17

3. Sample Holder Configuration. . . . . 22

VII. CONCLUSIONS. . . . . . . . . . . . . . 31

VIII. ACKNOWLEDGEMENTS • . . . . . . . . . . . . 35

IX. REFERENCES . . . . . . . . . . . . . 35

APPENDIX A. . . . . . . . . . . . . . . 37

APPENDIX B. . . . . . . . . . . . . . . . 41

APPENDIX C. . . . . . . . . . . . . . . . . 47 
1. Investigators participating in second international test programs and instrument make . • . . . . . . . . . . . 6

2. Mean temperature results $\left({ }^{\circ} \mathrm{C}\right)$. . . . . . . 14

3. Effect of T-thermocouple calibration heating mode only. . . . . . . . . . . . .

4. Effect of T-thermocouple calibration cooling mode only. . . . . . . . . . . . . .

5. Mean temperature results $\left({ }^{\circ} \mathrm{C}\right)$ for thermocouple place in the sample axially (Code 00). . .

6. Mean temperature results $\left({ }^{\circ} \mathrm{C}\right)$ for thermocouple place in contact with the sample holder axially (Code 03). . . . . . . . . .

7. Mean temperature results $\left({ }^{\circ} \mathrm{C}\right)$ for thermocouple placed in the reference axially (Code 10). .

8. Mean temperature results $\left({ }^{\circ} \mathrm{C}\right)$ for thermocouple placed geometrically equivalent to the sample and reference non-axially (Code 21).....

9. Mean temperature results $\left({ }^{\circ} \mathrm{C}\right)$ for thermocouple placed geometrically midway between sample and reference axially (Code 30). . . . .

10. Major sample holder configurations reported. . 23

11. Mean temperature results $\left({ }^{\circ} \mathrm{C}\right)$ for sample holder: cylindrical block, uncovered cylindrical wells (Code 002) . . . . . . 24

12. Mean temperature results $\left({ }^{\circ} \mathrm{C}\right)$ for sample holder: cylindrical block, loosely covered cylindrical wells (Code 012) . . . . . . 24

13. Mean temperature results $\left({ }^{\circ} \mathrm{C}\right)$ for sample holder: shallow cup, uncovered (Code 402) • 25

14. Mean temperature results $\left({ }^{\circ} \mathrm{C}\right)$ for sample holder: equal cup, uncovered (Code 502) . . 25 
15. Mean temperature results $\left({ }^{\circ} \mathrm{C}\right)$ for sample holder: deep cup, uncovered, bottom uniformly $=$ wall $($ Code 602$)$. . . . . 26

16. Mean temperature results $\left({ }^{\circ} \mathrm{C}\right)$ for sample holder: deep cup, uncovered, bottom nonuniformly $=$ wall $($ Code 603$)$. . . . . 26

17. Mean temperature results $\left({ }^{\circ} \mathrm{C}\right)$ for sample holder: deep cup, uncovered, bottom uniformly $>$ wall (Code 604) . . . . . 27

18. Mean temperature results $\left({ }^{\circ} \mathrm{C}\right)$ for sample holder: capillary, loosely covered (Code 701)............ 27

19. Peak resolution in $4: 1$ mixtures (by weight of $\mathrm{SiO}_{2}$ and $\mathrm{K}_{2} \mathrm{SO}_{4}$............ 31

\section{LIST OF FIGURES}

Figure No.

1. Deviations from the mean value as reported by the 34 investigators (submitted to the Standards Committee of ICTA). . . . . . 9

2. Peak resolution from base-line measurements (see also Table 19)......... 30

3. Data from 34 cooperating investigators for each of the 10 substances (submitted to the Standards Committee of the ICTA). . . 34 

STANDARD REFERENCE MATERIALS:

SELECTION OF DIFFERENTIAL THERMAL ANALYSIS TEMPERATURE STANDARDS THROUGH A COOPERATIVE STUDY, (SRM 758, 759, 760)

H. G. McAdie

Ontario Research Foundation

Toronto, Ontario, Canada

Paul D. Garn

The University of Akron

Akron, Ohio 44325

and

Oscar Menis

Analytical Chemistry Division

Institute for Materials Research

National Bureau of Standards

Washington, D. C. 20234

The testing and evaluation program leading to the certification of 10 materials as Standard Reference Materials NBS 758,759 , and 760 , for calibrating the temperature scale for thermal analysis is described. The international cooperative testing program was set up on the basis of a preliminary program initiated in 1966. Thirty-four laboratories reported to the Standards Committee of the International Confederation on Thermal Analysis. The results were obtained on a variety of apparatus under their conditions of experimentation, except that the heating rate was prescribed in the range of 4 to $10{ }^{\circ} \mathrm{C}$ per minute. The data were processed to obtain means and measures of scatter, not only in total, but separated in terms of a number of sample number of sample holder parameters. The sample holder geometry was the only parameter having a clear effect on the extrapolated onset and peak temperatures. The effects of thermocouple position and calibration were tested, but no significant effect was found. The heating rate has only a small effect, tending to increase the spread of onset and peak temperature values from the DTA are somewhat higher than the thermodynamic equilibrium values reported in the literature. Based on the mean values from all the laboratories the standard deviation was 5 to $8{ }^{\circ} \mathrm{C}$, which includes the bias between laboratories as well as measurement errors.

Key words: DTA; International Confederation on Thermal Analysis; international cooperative testing; Standard Reference Materials NBS 758, 759, 760; temperature scale; thermal analysis. 


\section{INTRODUCTION}

The need for dynamic temperature standards for differential thermal analysis (DTA) has been recognized by a number of agencies, but no substantial effort to provide these standards was made prior to the formation of the Committee on Standardization of the International Confederation for Thermal Analysis (ICTA). That Committee began an intensive study of the problems in 1966. The National Bureau of Standards participated in the planning and implementation of a test program designed to screen proposed standards. The Committee members provided liaison with related organizations in other countries.

By 1967, priorities had been established and a number of materials were tested within the scope of the highest priority, viz. inorganic specimens within the ambient to $100{ }^{\circ} \mathrm{C}$ temperature range. Ehoice of material was restricted to those having first order solid state phase changes in the appropriate temperature ranges. Melting points were excluded because several types of specimen holders could not retain liquids, and decomposition processes were considered to be unsuitable because the atmosphere could not be controlled in many apparatus. It was clearly defined that these standards are intended for calibration of the temperature scale under the conditions of the experiment; any modification of the experimental conditions to facilitate the testing of the reference materials would defeat the purpose.

Samples of twelve materials were distributed to twentyfour laboratories for testing. In 1968 the data were evaluated and eight of the twelve were selected for large batch testing and certification. Sufficient quantities of each material were obtained to make a large number of sets of Standard Reference Materials. Because of increased interest in melting points as temperature standards, two high-purity metals, tin and indium, were added to the test program. 
Sets of samples were distributed to 34 laboratories in twelve countries. Data were sent to the Chairman to prepare for computations. Testing of these samples and evaluation of the data comprised the ICTA's Second International Test Program (SITP).

II. THE SECOND INTERNATIONAL TEST PROGRAM

The purposes of the SITP may be summarized:

1. To evaluate further the initial 8 materials as potential DTA temperature standards, and to evaluate 2 metal melting points for the same purpose.

2. To provide the experimental basis for certifying each bulk sample from which test samples were taken.

On the basis of data obtained from the Second International Test Programme, and the recommendation by its Committee on Standardization, ICTA joins with the National Bureau of Standards in certifying Standards Reference Materials 758, 759 and 760. The Appendices contain the copies of the certificates (Appendix C) and a proposed draft of procedures (Appendix A) submitted to the American Society for Testing Materials.

\section{III . MATERIALS}

Examination of a number of specimens of each potential DTA temperature standard was carried out by various Committee members, with recommendations being reported by correspondence.

A. Systems Criteria

It is appropriate to review the criteria on which potential systems for DTA temperature standards were selected: 1. Chemical stability - the material should not change on storage.

2. Chemical inertness - the material should not attack materials normally employed in instrument construction.

3. Transitions should be characterized adequately by equilibrium thermodynamic methods. 
4. Other thermal effects should occur at temperatures removed from the transition of interest.

5. Materials should not require pre-treatment.

6. Materials can be heated in normal atmospheres without secondary effects.

7. Materials should be available commercially in high purity.

8. Naturally occurring materials are not favored because of inhomogeneity.

9. Expensive and relatively rare materials would be unsuitable for eventual large-scale distribution.

B. Transition Criteria

While melting or freezing points have traditionally been used as temperature standards, it was decided that solid $I+$ Solid II first-order phase transitions would be preferable for use in dynamic DTA. The reasons for this decision were as follows:

1. Not all instrumentation can be used with samples which melt. A number of common sample holders will not contain liquids .

2. A number of recognized melting point standards (e.g. Pb, $\mathrm{Zn}$ ) may contaminate thermocouples and sample holders through alloy formation.

3. Use of metal melting points requires the ability to impose a truly inert atmosphere, particularly when the melting point is above a few hundred degrees. Not all DTA systems have this capability.

4. Use of standard reference organic compounds also requires good atmosphere control. Such materials may also present problems of decomposition and/or high vapor pressure which would eliminate use as standards.

5. On melting changes in other physical properties such as heat capacity, thermal conductivity, specific volume, are often much larger than those accompanying Solid I $\vec{\leftarrow}$ Solid II transitions. In the case of metals, high surface ten- 
sion may prevent a uniform film or liquid from conforming to the sample holder shape. Together with the presence of any oxide layer, this could cause considerable change in thermal contact and distortion of the record.

6. The effect of impurities on melting points is more pronounced than on Solid I $\vec{\leftarrow}$ Solid II transitions.

Subsequent to selection of eight provisional temperature standards for DTA, representations to the Committee were received in favor of including two low-temperature metal melting points, indium and tin. It was agreed by the Committee that these should form part of the SITP, while emphasizing the above reservations.

C. Selected Materials

The following materials were selected:

$\mathrm{KNO}_{3}$ - Supplied by U. S. National Bureau of Standards.

$\mathrm{KClO}_{4}$ - Hooker Chemical Ltd., Lot No. 11211.

$\mathrm{Ag}_{2} \mathrm{SO}_{4}$ - J. T. Baker Analyzed Reagent Powder, Catalog No. 3436, Lot No. 39230 .

$\mathrm{SiO}_{2}$ - Supplied by U. S. National Bureau of Standards. $\mathrm{K}_{2} \mathrm{SO}_{4}$ - J. T. Baker Analyzed Reagent Powder, Catalog No. 3282 , Lot No. 33157.

$\mathrm{K}_{2} \mathrm{CrO}_{4}$ - British Drug Houses Chemicals Ltd. "Analar" Grade, Catalog No. 10199 , Batch No. 821708/690922, to pass 100-mesh sieve; supplied courtesy of Stanton/ Redcroft Ltd., London, England.

$\mathrm{BaCO}_{3}$ - E. Merck, AG, Darmstadt, Zur Analyse reagent Catalog No. 1714, Lot No. 7383188; supplied courtesy of Aktiebolaget Atomenergi, Nylcöping, Sweden.

$\mathrm{SrCO}_{3}$ - J. T. Baker Analyzed Reagent Powder, Catalog No. 4026, Lot No. 25187.

In - Alpha Metals, Inc., UHP Spheres 40-80 mesh 99.999\% pure.

Sn - Alpha Meta1s, Inc., UPH Spheres 40-80 mesh 99.999\% pure. 
Table 1 lists the investigator and a general description of the equipment used.

A copy of the revised procedures and data report for the SITP appear in Appendix A. As part of the statistical design of the SITP, each investigator was supplied with a random sequence of the numbers 1 to 10 and requested to examine the samples in this sequence.

Table 1. Investigators participating in second international test programs and instrument make.

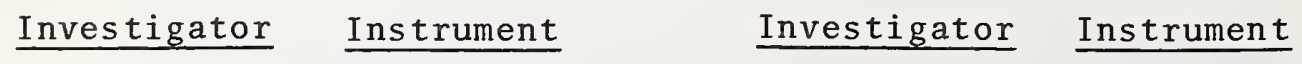

AUSTRALIA

Baum

CANADA

Bourgon

McAdie

FRANCE

Cizeron

Harmelin

Jegoude $z$

GERMANY

Hei de

Wiegmann

HUNGARY

Foldvari

Paulik

JAPAN

Kambe

Kato

Oinuma

otsuka
B.D.L. M-2

Stone KA-W

Rigaku Denki 80015

SWITZERLAND

Krien

Ostwald

Peters

Wiedemann

U.S.S.R.

Berg

Khripin

Koehler

Piloyan

Rassonkaya

Shklover

Hartmann \& Braun

Derivatograph

ADAMEL ATD
B.D.L. M-4

B.D.L. M-2

U. K.

Charsley

Mackenzie

Smith

Derivatograph

Derivatograph

SOUTH AFRICA

Krüger

Own design

SWEDEN

Forsyth
Rigaku Denki CN800I

Shimadzu DTA-20B-H

Mitamura 2-100 DTA

Chyo TRDA 1 - L
U.S.A.

Gallagher Garn

Menis

Oulton

Ware
Linseis $\mathrm{L} 61 / 1 \mathrm{M}$

Mettler Thermoanalyzer

Netzch

Mettler Thermoanalyzer I

Kurnakov Pyrometer PK-59

CKB UP, NTR-64

Own design

Derivatograph

CKB UP, NTR-62

CKB UP, NTR-62

Stanton 6-25

Own design

DuPont 900

DuPont 900

Own design

DuPont 900

Stone, LA-FS-2

Stone DTA-12B

Stone DS-2 


\section{DATA HANDLING}

A. Data Preparation

From descriptions submitted by each investigator, appropriate code designations for pertinent instrumental parameters were selected jointly by P. D. Garn and H. G. McAdie. Corrections to these designations were received at the following meeting of the Committee and incorporated in subsequent calculations. In cases where an investigator employed different instrumental parameters for different materials care was taken to separate data from these experiments.

Temperature and area data from each experiment were coded from the values supplied by each investigator. An "experiment" was defined as including the heating and cooling modes if both were carried out. No attempt was made to measure, review, check or correct these data, however, each chart record was examined in relation to the data being coded to reduce transcription errors and avoid misinterpretation. In cases where obvious discrepancies appeared, or where further information regarding instrumentation was required, details were obtained by correspondence.

A number of conventions were adopted:

1. Extrapolated onset temperature was defined as the intersection of the forward-extrapolated baseline with the backward-extrapolated initial side of the peak, as shown in Figure 1. The term "onset temperature" throughout this report refers to that point.

2. Where samples were cycled, only the first cycle data were coded EXCEPT when only the second cycle data were reported. It was assumed that data for $\mathrm{KNO}_{3}$ were those for the second cycle, in view of instructions given. In certain cases there was some doubt that this material had been cycled. In other cases data from the second cycle were not reported and it was necessary to use the first cycle results.

3. Replicate experiments from some investigators were made with identical sample weights. Where information to the 
contrary was lacking, these were treated as individual loadings of the sample holder, although it is possible that only one loading was made and the sample merely cycled.

4. Sample weights $\geq 1000 \mathrm{mg}$ were coded as $999.99 \mathrm{mg}$.

5. In cases where information recorded on the experimental charts differed from that in tables, or other typed summaries, the chart information was used.

B. Data Processing

Coded information was forwarded to P. D. Garn for processing in the computer at the University of Akron. IBM cards, each containing the data from a single experiment, were, punched and verified in the usual way. Appropriate corrections were made at the following meeting of the committee and duplicate sets of cards forwarded to 0 . Menis and H. G. McAdie. Certain corrections to data, received by correspondence too late for inclusion in earlier calculations were also made.

The basic computer program was revised in format, rather than in content. Information produced included:

mean

computed standard deviation(s)

maximum observation

minimum observation

number of observations $(N)$

code numbers of investigators whose data were

included in each of the above calculations,

for each of the following measurements:

heating: peak area

onset temperature

peak temperature

Cooling: peak area

onset temperature

peak temperature 


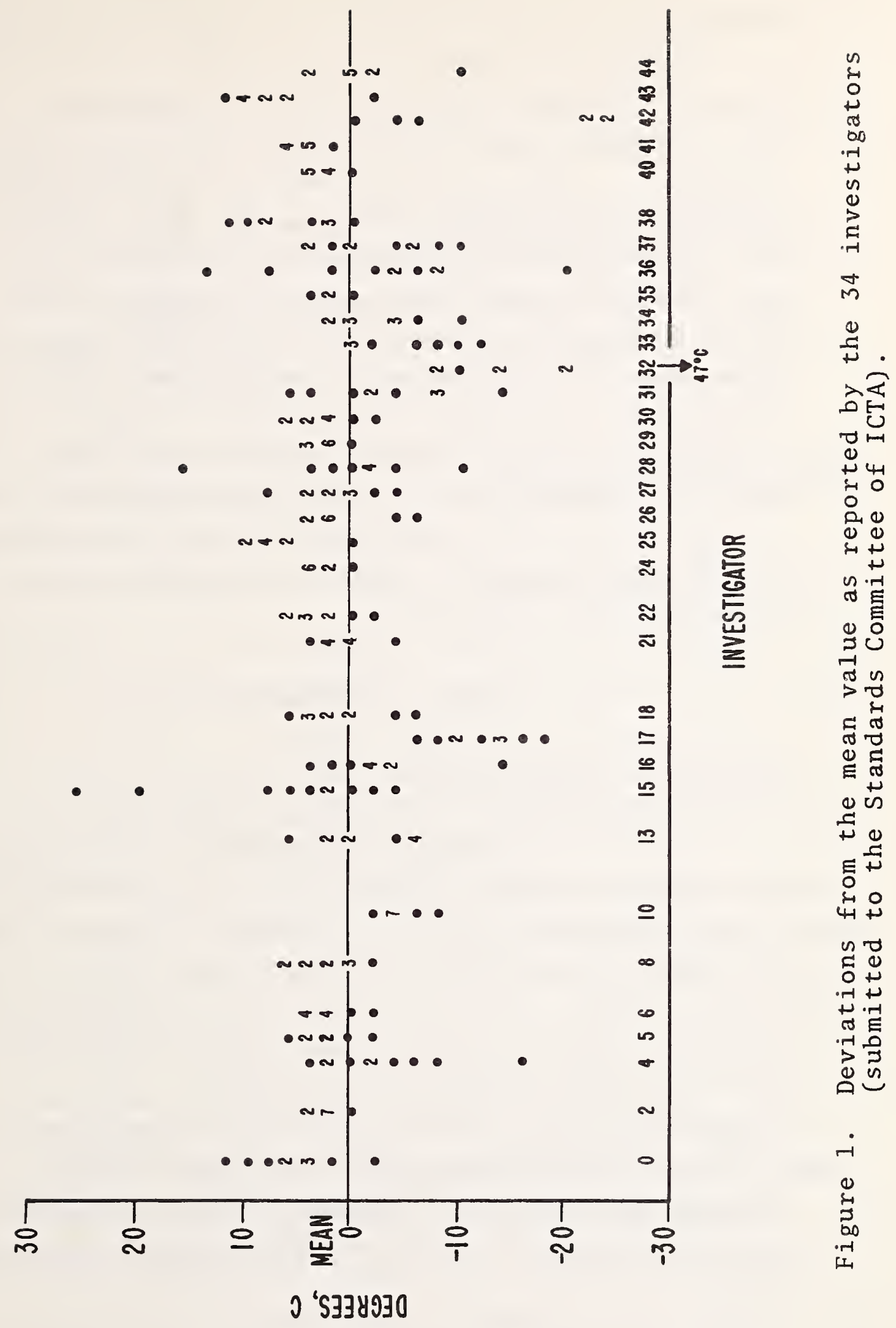


The sequence of steps in the data processing following the 1970 committee meeting was as follows:

1. Computations were made on a11 data as submitted.

2. In a separate program at the U. S. National Bureau of Standards, 0. Menis and colleagues prepared a ranking order for all compounds based on the onset temperature [1]. Replicate values from each investigator were averaged prior to preparation of this ranking, so that only the one temperature was used for each compound from each investigator. A number of tests were made for systematic deviations .

3. At the University of Akron, SITP data were used: to compute overall means for all data; to examine the effect of sample holder configuration; to examine the effect of thermocouple placement; and to examine the effect of thermocouple calibration.

\section{RESULTS - TEMPERATURE DATA}

A. Tests for Systematic Bias

Before proceeding with re-calculation of the data, a detailed review of the submitted temperatures was made by 0 . Menis and the members of the staff of the Engineering Statistics Division at the U. S. National Bureau of Standards to investigate the possibility of systematic bias in an investigator's data. Tests were also made to determine trends in deviations from the overall mean which might result from a number of sources within the test data.

Calculations and computer plots are summarized in Tables 2-19. The following conclusions are drawn: 1. Ranking order of onset temperature data indicated the scatter of results is due to differences between laboratories.

2. Youden plots showed no justification for removing an investigator from the test results on the basis of unaccept- 
able systematic bias, as determined by the mean deviation being greater than $\pm 3 \sigma$ calculated over all compounds and a11 investigators.

3. Some investigators showed better correlation than others, although generally good precision was observed in each laboratory.

4. Deviations from the overall respective mean temperatures increased in the following order of measurement positions: onset (heating); peak (heating); onset (cooling); peak (cooling). Thus, the average onset temperature obtained by a given investigator showed the smallest deviation from the mean of all data for that point.

5. No trend could be established in deviations from the mean for particular compounds, i.e. no compound gave unusually precise or imprecise results.

6. No trend could be established in deviations from the overall mean in relation to sample weight, sample holder configuration, well description, sample holder material, heat sink material, gas flow rate, gas flow pattern, $\Delta T$ couple characteristics, $\Delta T$ couple location. In each case the test was based only on the deviation of each investigator's average onset temperature from the mean of all onset temperatures for the same compound.

7. A trend to increasing difference between onset and peak temperatures on heating was noted with increasing heating rate. Wider data scatter was also observed with increasing heating rate.

On the above bases it was appropriate to include all data, as received from the various investigators, in the eventual analysis of SITP results. In a very few isolated cases individual values were excluded on the basis of an error in test conditions employed or a gross discrepancy (significantly greater than $\pm 3 \sigma$ ) for a single datum point. 
B. Mean Temperature Results

Following the tests for bias and deviation trends described in Section $6 \mathrm{~A}$, incorporating corrections outlined in Section 5B, a complete re-computation of the data was made. On the basis of results obtained, the following observations may be made:

1. The average standard deviation on heating for all compounds was $\pm 6{ }^{\circ} \mathrm{C}$ for the onset temperature, and $\pm 7{ }^{\circ} \mathrm{C}$ for the peak temperature.

2. The average standard deviation on cooling for all compounds was $\pm 8{ }^{\circ} \mathrm{C}$ for the onset temperature and $\pm 10{ }^{\circ} \mathrm{C}$ for the peak temperature.

3. The spread of temperatures reported for a given transition on heating varied from 22 to $51{ }^{\circ} \mathrm{C}$ for the onset temperature and from 23 to $51{ }^{\circ} \mathrm{C}$ for the peak temperatures. In both cases there was a tendency toward larger spread at higher transition temperatures.

4. The spread of temperatures reported for a given transition on cooling varied from 16 to $76^{\circ} \mathrm{C}$ for the onset temperature and from 16 to $83^{\circ} \mathrm{C}$ for the peak temperature. The freezing point of $\mathrm{Sn}$ and the $\mathrm{S}_{\mathrm{II}} \rightarrow \mathrm{S}_{\mathrm{I}}$ transitions in $\mathrm{Ag}_{2} \mathrm{SO}_{4}, \mathrm{BaCO}_{3}$, and $\mathrm{SrCO}_{3}$ exhibited particularly wide spreads in both onset and peak temperatures on cooling.

5. With the exception of $\mathrm{Ag}_{2} \mathrm{SO}_{4}$, the mean onset temperatures on heating averaged $-1{ }^{\circ} \mathrm{C}$ of the accepted equilibrium transition temperature [2]. For $\mathrm{Ag}_{2} \mathrm{SO}_{4}$ an equilibrium temperature of $430 \pm 3$ degrees [3] appears to be more reliable than the 412 degree value cited [2].

6. With the exception of $\mathrm{Ag}_{2} \mathrm{SO}_{4}$, the mean deviation of the onset temperature on heating from the accepted equilibrium transition temperature [2] was $-1{ }^{\circ} \mathrm{C}$. Accepting that an equilibrium transition temperature for $\mathrm{Ag}_{2} \mathrm{SO}_{4}$ of $430 \pm 3{ }^{\circ} \mathrm{C}$ [3] is more reliable than the $412{ }^{\circ} \mathrm{C}$ cited by NBS [2], the mean deviation of the onset temperature from the equilibrium transition temperature was $-1.5{ }^{\circ} \mathrm{C}$ with a spread of -6 to 
$+3{ }^{\circ} \mathrm{C}$. The mean deviation of peak temperatures on heating was $+6{ }^{\circ} \mathrm{C}$ with a spread of +1 to $+9{ }^{\circ} \mathrm{C}$ from the equilibrium transition temperature.

7. On cooling, mean onset temperatures for $\mathrm{KNO}_{3}$, In, $\mathrm{SiO}_{2}$, $\mathrm{K}_{2} \mathrm{SO}_{4}$ and $\mathrm{K}_{2} \mathrm{CrO}_{4}$ were within -6 to $+2{ }^{\circ} \mathrm{C}$ of the equilibrium transition temperature. For these same compounds mean peak temperatures ranged from -4 to $-8{ }^{\circ} \mathrm{C}$ of the equilibrium value. For $\mathrm{Sn}, \mathrm{KClO}_{4} \cdot \mathrm{Ag}_{2} \mathrm{SO}_{4}, \mathrm{BaCO}_{3}$ and $\mathrm{SrCO}_{3}$. mean onset and peak temperatures were at least $13{ }^{\circ} \mathrm{C}$ below accepted equilibrium values.

8. Mean temperatures for $\mathrm{SiO}_{2}$ and $\mathrm{K}_{2} \mathrm{SO}_{4}$ in a $4: 1$ mixture by weight were not statistically different from those for the individual constituent, so that no effect of dilution was evident. No difference in precision was noted.

The values for Standard Reference Materials 758, 759, and 760 are the mean values from Table 2. The standard deviations in Table 2 reflect principally the variation between types of instrumentation and other experimental parameters. Within a laboratory or a single type of instrument the standard deviation will ordinarily be much smaller. The quoted standard deviations are not uncertainties in the temperatures of the transitions. The materials from a given batch will behave the same way in one laboratory as in another. More extensive tests (for homogeneity) of potassium nitrate and quartz using a single instrument, yielded values with ranges of $1{ }^{\circ} \mathrm{C}$ for each compound [4]. The deviation measured by an individual apparatus is a measure only of that apparatus difference from a norm which is close to the equilibrium value.

Note that agreement or disagreement with the equilibrium value is not essential to the use of these Standard Reference Materials in comparison of other data. It is only necessary that a single value be accepted. This could be the known 
thermodynamics value. Deviations of different laboratories from the same accepted points are used to calibrate differences in the individual instruments and hence to relate interlaboratory data.

Table 2. Mean temperature results $\left({ }^{\circ} \mathrm{C}\right)$.

\begin{tabular}{|c|c|c|c|c|c|c|c|}
\hline \multirow[b]{2}{*}{ Compound } & \multirow{2}{*}{$\mathrm{T}_{\mathrm{eq}}^{\mathrm{a}}$} & \multicolumn{3}{|c|}{ Heating } & \multicolumn{3}{|c|}{ Cooling } \\
\hline & & $\underline{N}$ & Onset & Peak & $\underline{N}$ & Onset & Peak \\
\hline $\mathrm{KNO}_{3}$ & 127.7 & 63 & $\begin{array}{c}128 \pm 5 \\
(112-149)\end{array}$ & $\begin{array}{c}135 \pm 6 \\
(126-160)\end{array}$ & 31 & $\begin{array}{c}122 \pm 4 \\
(112-128)\end{array}$ & $\begin{array}{c}119 \pm 4 \\
(110-126)\end{array}$ \\
\hline In & 157 & $59 / 60$ & $\begin{array}{c}154 \pm 6 \\
(140-162)\end{array}$ & $\begin{array}{c}159 \pm 6 \\
(140-171)\end{array}$ & $29 / 27$ & $\begin{array}{c}154 \pm 4 \\
(146-163)\end{array}$ & $\begin{array}{c}150 \pm 4 \\
(139-155)\end{array}$ \\
\hline $\mathrm{Sn}$ & 231.9 & $57 / 59$ & $\begin{array}{c}230 \pm 5 \\
(217-240)\end{array}$ & $\begin{array}{c}237 \pm 6 \\
(226-256)\end{array}$ & $22 / 18$ & $\begin{array}{r}203 \pm 16 \\
(168-222)\end{array}$ & $\begin{array}{r}203 \pm 17 \\
(176-231)\end{array}$ \\
\hline $\mathrm{KClO}_{4}$ & 299.5 & $67 / 66$ & $\begin{array}{c}299 \pm 6 \\
(280-310)\end{array}$ & $\begin{array}{c}309 \pm 8 \\
(296-330)\end{array}$ & 31 & $\begin{array}{c}287 \pm 4 \\
(278-296)\end{array}$ & $\begin{array}{c}283 \pm 5 \\
(274-295)\end{array}$ \\
\hline $\mathrm{Ag}_{2} \mathrm{SO}_{4}$ & $430^{b}$ & 64 & $\begin{array}{c}424 \pm 7 \\
(400-439)\end{array}$ & $\begin{array}{c}433 \pm 7 \\
(405-452)\end{array}$ & $30 / 27$ & $\begin{array}{r}399 \pm 14 \\
(337-413)\end{array}$ & $\begin{array}{r}399 \pm 15 \\
(336-419)\end{array}$ \\
\hline $\mathrm{SiO}_{2}$ & 573 & 66 & $\begin{array}{c}571 \pm 5 \\
(552-581)\end{array}$ & $\begin{array}{c}574 \pm 5 \\
(560-588)\end{array}$ & $34 / 36$ & $\begin{array}{c}572 \pm 3 \\
(565-577)\end{array}$ & $\begin{array}{c}569 \pm 4 \\
(559-575)\end{array}$ \\
\hline $\mathrm{K}_{2} \mathrm{SO}_{4}$ & 583 & 67 & $\begin{array}{c}582 \pm 7 \\
(560-598)\end{array}$ & $\begin{array}{c}588 \pm 6 \\
(575-608)\end{array}$ & $30 / 31$ & $\begin{array}{c}582 \pm 4 \\
(572-587)\end{array}$ & $\begin{array}{c}577 \pm 8 \\
(551-587)\end{array}$ \\
\hline $\mathrm{K}_{2} \mathrm{CrO}_{4}$ & 665 & 63 & $\begin{array}{c}665 \pm 7 \\
(640-678)\end{array}$ & $\begin{array}{c}673 \pm 6 \\
(656-692)\end{array}$ & 31 & $\begin{array}{c}667 \pm 5 \\
(652-675)\end{array}$ & $\begin{array}{c}661 \pm 8 \\
(630-671)\end{array}$ \\
\hline $\mathrm{BaCO}_{3}$ & 810 & 71 & $\begin{array}{c}808 \pm 8 \\
(783-834)\end{array}$ & $\begin{array}{c}819 \pm 8 \\
(800-841)\end{array}$ & 29 & $\begin{array}{r}767 \cdot \pm 13 \\
(742-790)\end{array}$ & $\begin{array}{r}752 \pm 16 \\
(714-779)\end{array}$ \\
\hline $\mathrm{SrCO}_{3}$ & 925 & $67 / 66$ & $\begin{array}{c}928 \pm 7 \\
(905-948)\end{array}$ & $\begin{array}{c}938 \pm 9 \\
(910-961)\end{array}$ & $31 / 30$ & $\begin{array}{r}904 \pm 15 \\
(875-944)\end{array}$ & $\begin{array}{r}897 \pm 13 \\
(868-920)\end{array}$ \\
\hline $\begin{array}{l}\mathrm{SiO}_{2} \text { in } \\
4: 1_{\text {mixture }}\end{array}$ & & $42 / 40$ & $\begin{array}{c}572 \pm 6 \\
(560-583)\end{array}$ & $\begin{array}{c}575 \pm 5 \\
(565-590)\end{array}$ & $22 / 23$ & $\begin{array}{c}574 \pm 3 \\
(570-583)\end{array}$ & $\begin{array}{c}570 \pm 4 \\
(563-582)\end{array}$ \\
\hline $\begin{array}{l}\mathrm{K}_{2} \mathrm{SO}_{4} \text { in } \\
4: 1 \text { mixture }\end{array}$ & & $32 / 39$ & $\begin{array}{c}582 \pm 5 \\
(572-595)\end{array}$ & $\begin{array}{c}586 \pm 6 \\
(574-600)\end{array}$ & $22 / 23$ & $\begin{array}{c}584 \pm 4 \\
(570-595)\end{array}$ & $\begin{array}{c}582 \pm 4 \\
(570-594)\end{array}$ \\
\hline
\end{tabular}

${ }^{a}$ See reference [2].

${ }^{b}$ See reference [3]. 
C. Influence of Experimental Parameters

The data coding procedures allow for the evaluation of the influence of 9 instrumental parameters upon any reported temperature for a given compound:

1. sample weight

2. dilution

3. sample holder configuration and construction

4. gas flow characteristics

5. characteristics of the $\Delta T$ thermocouple

6. characteristics and location of the T-thermocouple

7. effect of thermocouple calibrated.

8. method of temperature measurement

9. heating rate

The effect of heating rate was not statistically significant in the First International Test Program (FITP). While a heating rate in the range 4 to $10{ }^{\circ} \mathrm{C} \mathrm{min}-1$ was requested in the SITP (Appendix B), actual values reported ranged from 2 to $11{ }^{\circ} \mathrm{Cmin}^{-1}$ and the influence of this parameter was not examined at this time.

1. Effect of Thermocouple Calibration

An approximately equal number of investigators used calibrated and uncalibrated T-thermocouples. Of the 18 investigators who stated they employed "calibrated" T-thermocouples, 11 reported calibration at more than one temperature over the range of interest to the SITP. From the data presented in Table 3 the following observations may be made for the HEATING mode:

1. There is no statistically significant effect of T-thermocouple calibration with respect to the heating mode.

2. For 9 of the 10 materials, the mean extrapolated onset temperature for a given compound obtained using a calibrated $\mathrm{T}$-thermocouple is 1 to $8{ }^{\circ} \mathrm{C}$ below that obtained using the uncalibrated T-thermocouple. The same comparison holds for peak temperatures. While the trend in both 
cases is evident, the differences do not exceed the precision of the data.

3. The mean standard deviation of the onset temperature on heating is virtually the same for calibrated and uncalibrated $\mathrm{T}$-thermocouples, however, with respect to peak temperature the mean standard deviation is higher for uncalibrated $\mathrm{T}$-thermocouples.

4. For both calibrated and uncalibrated T-thermocouples there is no appreciable variation of the standard deviation of either the onset or peak temperatures with temperature.

Table 3. Effect of $\mathrm{T}$-thermocouple calibration heating mode only.

\begin{tabular}{|c|c|c|c|c|c|c|}
\hline \multirow{2}{*}{ Compound } & \multicolumn{3}{|c|}{ Calibrated } & \multicolumn{3}{|c|}{ Uncalibrated } \\
\hline & $\mathrm{N}$ & Onset & Peak & $\underline{N}$ & Onset & $\underline{\text { Peak }}$ \\
\hline $\mathrm{KNO}_{3}$ & 30 & $127 \pm 6$ & $134 \pm 5$ & 33 & $129 \pm 5$ & $136 \pm 8$ \\
\hline In & $31 / 32$ & $153 \pm 6$ & $158 \pm 6$ & 28 & $155 \pm 5$ & $160 \pm 5$ \\
\hline Sn & $29 / 31$ & $229 \pm 5$ & $236 \pm 5$ & 26 & $232 \pm 5$ & $238 \pm 6$ \\
\hline $\mathrm{KClO}_{4}$ & $32 / 31$ & $298 \pm 7$ & $308 \pm 5$ & 35 & $301 \pm 4$ & $309 \pm 9$ \\
\hline $\mathrm{Ag}_{2} \mathrm{SO}_{4}$ & 31 & $425 \pm 6$ & $434 \pm 5$ & 33 & $424 \pm 8$ & $432 \pm 9$ \\
\hline $\mathrm{SiO}_{2}$ & 34 & $569 \pm 5$ & $573 \pm 4$ & 31 & $573 \pm 5$ & $576 \pm 5$ \\
\hline $\mathrm{K}_{2} \mathrm{SO}_{4}$ & 35 & $580 \pm 7$ & $587 \pm 5$ & 32 & $584 \pm 7$ & $590 \pm 7$ \\
\hline $\mathrm{K}_{2} \mathrm{CrO}_{4}$ & 31 & $664 \pm 5$ & $671 \pm 4$ & 32 & $667 \pm 8$ & $675 \pm 8$ \\
\hline $\mathrm{BaCO}_{3}$ & 38 & $805 \pm 7$ & $817 \pm 7$ & 33 & $811 \pm 9$ & $821 \pm 9$ \\
\hline $\mathrm{SrCO}_{3}$ & $38 / 37$ & $925 \pm 6$ & $935 \pm 8$ & 29 & $933 \pm 7$ & $943 \pm 8$ \\
\hline
\end{tabular}

While fewer data were available on the effect of thermocouple calibration in the COOLING mode (Table 4) the following observations may be made:

1. There is no statistically significant effect of T-thermocouple calibration with respect to the cooling mode.

2. The mean onset temperature for a given compound obtained using a calibrated thermocouple ranged from 0 to $18{ }^{\circ} \mathrm{C}$ below that obtained using an uncalibrated thermocouple. 
3. The mean standard deviation of both onset and peak temperatures is virtually the same for calibrated and uncalibrated T-thermocouples.

4. For both calibrated and uncalibrated T-thermocouples there is no apparent variation of the standard deviation of either the onset or peak temperatures with temperature.

Table 4. Effect of T-thermocouple calibration cooling mode only.

\begin{tabular}{|c|c|c|c|c|c|c|}
\hline \multirow[b]{2}{*}{ Compound } & \multicolumn{3}{|c|}{ Calibrated } & \multicolumn{3}{|c|}{ Uncalibrated } \\
\hline & $\underline{N}$ & Onset & Peak & $\underline{N}$ & Onset & Peak \\
\hline $\mathrm{KNO}_{3}$ & 17 & $123 \pm 4$ & $119 \pm 4$ & 14 & $121 \pm 4$ & $119 \pm 4$ \\
\hline In & $17 / 16$ & $154 \pm 4$ & $149 \pm 2$ & $12 / 11$ & $155 \pm 4$ & $151 \pm 6$ \\
\hline Sn & $16 / 12$ & $199 \pm 16$ & $195 \pm 13$ & 6 & $217 \pm 4$ & $220 \pm 9$ \\
\hline $\mathrm{KClO}_{4}$ & 17 & $287 \pm 5$ & $283 \pm 6$ & 14 & $287 \pm 3$ & $284 \pm 4$ \\
\hline $\mathrm{Ag}_{2} \mathrm{SO}_{4}$ & $16 / 13$ & $399 \pm 8$ & $400 \pm 10$ & 14 & $399 \pm 19$ & $398 \pm 20$ \\
\hline $\mathrm{SiO}_{2}$ & $20 / 22$ & $572 \pm 3$ & $569 \pm 4$ & 13 & $571 \pm 3$ & $569 \pm 4$ \\
\hline $\mathrm{K}_{2} \mathrm{CrO}_{4}$ & $18 / 19$ & $582 \pm 5$ & $574 \pm 8$ & 12 & $584 \pm 2$ & $581 \pm 3$ \\
\hline $\mathrm{K}_{2} \mathrm{CrO}_{4}$ & 19 & $666 \pm 5$ & $658 \pm 9$ & 12 & $668 \pm 4$ & $665 \pm 5$ \\
\hline $\mathrm{BaCO}_{3}$ & 18 & $765 \pm 13$ & $747 \pm 17$ & 11 & $771 \pm 13$ & $759 \pm 12$ \\
\hline $\mathrm{SrCO}_{3}$ & 22 & $900 \pm 9$ & $892 \pm 10$ & $9 / 8$ & $913 \pm .21$ & $909 \pm 13$ \\
\hline
\end{tabular}

\section{T-Thermocouple Placement}

The following locations for the $T$-thermocouple existed in the various instruments used in the SITP.

Code 00 In the sample, axially

01 In the sample, non-axially

02 In the sample, edge

03 In contact with the sample holder, axially

04 In contact with the sample holder, edge

06 In contact with the sample holder support or heat sink, axially 
10 In the reference, axially

13 In contact with the reference holder, axially

18 In contact with the reference holder support or heat sink, edge

20 Location geometrically equivalent to sample and reference, axially

21 Location geometrically equivalent to sample and reference, non-axially

30 Location geometrically midway between sample and reference, axially

40 Shield surrounding sample and reference in a thermally equivalent way

Of these, Code Nos. 01, 02, 05, 06, 13, 20 and 40 were confined to 1 to 2 investigators reporting 1 to 4 data points. While means were computed in all possible cases, the data have not been included in Tables 5 to 9 since the influence of these T-thermocouple locations cannot be evaluated from such limited results. This is a reflection of the variety of instrumental designs involved in contributions to the SITP, rather than a criticism of any particular investigator.

If we restrict data evaluation first to the HEATING mode, the following general comments may be made:

1. For the extrapolated onset temperature, position 30 generally produced low mean values. Position 21 generally produced high mean values except in the case of melting metals. Other positions showed less evident order. The differences did not exceed the sum of respective standard deviations.

2. For the peak temperature, position 30 generally produced low mean values while position 10 generally produced high mean values. Other positions showed less evident order. Again, the differences did not exceed the sum of standard deviations .

3. For the onset temperature, positions $00,03,10$ and 21 produced mean values ranging within $\pm 3{ }^{\circ} \mathrm{C}$ of the accepted 
Table 5. Mean temperature results $\left({ }^{\circ} \mathrm{C}\right)$ for thermocouple place in the sample axially (Code 00).

\begin{tabular}{|c|c|c|c|c|c|c|}
\hline \multirow[b]{2}{*}{ Compound } & \multicolumn{3}{|c|}{ Heating } & \multicolumn{3}{|c|}{ Cooling } \\
\hline & $\underline{N}$ & Onset & Peak & $\underline{N}$ & Onset & Peak \\
\hline $\mathrm{KNO}_{3}$ & 10 & $128 \pm 6$ & $133 \pm 5$ & 8 & $125 \pm 4$ & $123 \pm 3$ \\
\hline In & 8 & $154 \pm 3$ & $157 \pm 4$ & $6 / 4$ & $158 \pm 5$ & $154 \pm 1$ \\
\hline $\mathrm{Sn}$ & $6 / 8$ & $230 \pm 2$ & $233 \pm 2$ & $4 / 3$ & $203 \pm 10$ & $219 \pm 19$ \\
\hline $\mathrm{KC} \mathrm{O}_{4}$ & 10 & $301 \pm 3$ & $305 \pm 3$ & 8 & $291 \pm 5$ & $290 \pm 4$ \\
\hline $\mathrm{Ag}_{2} \mathrm{SO}_{4}$ & 10 & $423 \pm 7$ & $429 \pm 8$ & $8 / 6$ & $403 \pm 6$ & $412 \pm 4$ \\
\hline $\mathrm{SiO}_{2}$ & 10 & $572 \pm 2$ & $574 \pm 2$ & 8 & $573 \pm 4$ & $571 \pm 4$ \\
\hline $\mathrm{K}_{2} \mathrm{SO}_{4}$ & 9 & $582 \pm 3$ & $586 \pm 2$ & 7 & $584 \pm 2$ & $582 \pm 2$ \\
\hline $\mathrm{K}_{2} \mathrm{CrO}_{4}$ & 8 & $666 \pm 2$ & $670 \pm 3$ & 6 & $668 \pm 1$ & $665 \pm 1$ \\
\hline $\mathrm{BaCO}_{3}$ & 8 & $809 \pm 5$ & $817 \pm 3$ & $6 / 4$ & $772 \pm 16$ & $758 \pm 23$ \\
\hline $\mathrm{SrCO}_{3}$ & 8 & $926 \pm 4$ & $930 \pm 4$ & $6 / 4$ & $895 \pm 5$ & $908 \pm 7$ \\
\hline
\end{tabular}

Table 6. Mean temperature results $\left({ }^{\circ} \mathrm{C}\right)$ for thermocouple place in contact with the sample holder axially (Code 03).

\begin{tabular}{|c|c|c|c|c|c|c|}
\hline \multirow[b]{2}{*}{ Compound } & \multicolumn{3}{|c|}{ Heating } & \multicolumn{3}{|c|}{ Cooling } \\
\hline & $\underline{N}$ & Onset & Peak & $\underline{N}$ & Onset & Peak \\
\hline $\mathrm{KNO}_{3}$ & 16 & $127 \pm 7$ & $135 \pm 6$ & 1 & 116 & 116 \\
\hline In & 16 & $154 \pm 7$ & $158 \pm 5$ & 1 & 146 & 145 \\
\hline Sn & 16 & $229 \pm 7$ & $236 \pm 6$ & 2 & 169 & 176 \\
\hline $\mathrm{KC} \mathrm{O}_{4}$ & 16 & $299 \pm 7$ & $308 \pm 7$ & 2 & 278 & 278 \\
\hline $\mathrm{Ag}_{2} \mathrm{SO}_{4}$ & 16 & $425 \pm 7$ & $434 \pm 7$ & 2 & 405 & 411 \\
\hline $\mathrm{SiO}_{2}$ & 16 & $570 \pm 7$ & $574 \pm 6$ & 2 & 571 & 560 \\
\hline $\mathrm{K}_{2} \mathrm{SO}_{4}$ & 16 & $582 \pm 7$ & $588 \pm 5$ & 2 & 573 & 553 \\
\hline $\mathrm{K}_{2} \mathrm{CrO}_{4}$ & 16 & $664 \pm 6$ & $672 \pm 4$ & 2 & 658 & 635 \\
\hline $\mathrm{BaCO}_{3}$ & 16 & $806 \pm 8$ & $815 \pm 8$ & 2 & 744 & 717 \\
\hline $\mathrm{SrCO}_{3}$ & 16 & $927 \pm 10$ & $936 \pm 10$ & 2 & 883 & 869 \\
\hline
\end{tabular}


Table 7. Mean temperature results $\left({ }^{\circ} \mathrm{C}\right)$ for the rmocouple placed in the reference axially (Code 10).

\begin{tabular}{|c|c|c|c|c|c|c|c|}
\hline \multirow[b]{2}{*}{ Compound } & \multicolumn{4}{|c|}{ Heating } & \multicolumn{3}{|c|}{ Cooling } \\
\hline & $\underline{N}$ & Onset & Peak & & $\underline{N}$ & Onset & Peak \\
\hline $\mathrm{KNO}_{3}$ & 6 & $129 \pm 1$ & $139 \pm 1$ & & 4 & $123 \pm 2$ & $119 \pm 4$ \\
\hline In & 4 & $158 \pm 1$ & $165 \pm 2$ & 2 & 4 & $154 \ddagger 1$ & $150 \pm 3$ \\
\hline Sn & 4 & $233 \pm 1$ & $243 \pm 2$ & 2 & 4 & $201 \pm 3$ & $200 \pm 3$ \\
\hline $\mathrm{KC} \mathrm{O}_{4}$ & 7 & $300 \pm 2$ & $315 \pm s$ & 9 & 4 & $289 \pm 0$ & $282 \pm 2$ \\
\hline $\mathrm{Ag}_{2} \mathrm{SO}_{4}$ & 7 & $420 \pm 10$ & $432 \pm]$ & 12 & 4 & $402 \pm 5$ & $399 \pm 4$ \\
\hline $\mathrm{SiO}_{2}$ & 9 & $570 \pm 4$ & $573 \pm ?$ & 3 & 6 & $575 \pm 1$ & $571 \pm 1$ \\
\hline $\mathrm{K}_{2} \mathrm{SO}_{4}$ & 9 & $580 \pm 10$ & $591 \pm$ & 7 & 4 & $585 \pm 1$ & $578 \pm 1$ \\
\hline $\mathrm{K}_{2} \mathrm{CrO}_{4}$ & 7 & $659 \pm 11$ & $675 \pm$ & 10 & 4 & $669 \pm 1$ & $662 \pm 1$ \\
\hline $\mathrm{BaCO}_{3}$ & 9 & $806 \pm 8$ & $818 \pm$ & 7 & 4 & $771 \pm 1$ & $761 \pm 6$ \\
\hline $\mathrm{SrCO}_{3}$ & 9 & $928 \pm 1$ & $944 \pm$ & 4 & 5 & $907 \pm 7$ & $898 \pm 3$ \\
\hline
\end{tabular}

Table 8. Mean temperature results $\left({ }^{\circ} \mathrm{C}\right)$ for thermocouple placed geometrically equivalent to the sample and reference non-axially (Code 21).

\begin{tabular}{|c|c|c|c|c|c|c|}
\hline \multirow[b]{2}{*}{ Compound } & \multicolumn{3}{|c|}{ Heating } & \multicolumn{3}{|c|}{ Cooling } \\
\hline & $\underline{N}$ & Onset & Peak & $\underline{N}$ & Onset & Peak \\
\hline $\mathrm{KNO}_{3}$ & 16 & $127 \pm 4$ & $132 \pm 4$ & 12 & $120 \pm 3$ & $117 \pm 3$ \\
\hline In & 17 & $153 \pm 6$ & $158 \pm 5$ & 12 & $152 \pm 2$ & $148 \pm 4$ \\
\hline Sn & 17 & $229 \pm 5$ & $236 \pm 5$ & $12 / 9$ & $210 \pm 14$ & $206 \pm 14$ \\
\hline $\mathrm{KClO}_{4}$ & $16 / 15$ & $299 \pm 5$ & $306 \pm 4$ & 11 & $285 \pm 2$ & $280 \pm 4$ \\
\hline $\mathrm{Ag}_{2} \mathrm{SO}_{4}$ & 16 & $427 \pm 4$ & $433 \pm 3$ & $10 / 8$ & $389 \pm 20$ & $384 \pm 21$ \\
\hline $\mathrm{SiO}_{2}$ & 16 & $572 \pm 5$ & $575 \pm 4$ & 12 & $570 \pm 3$ & $567 \pm 2$ \\
\hline $\mathrm{K}_{2} \mathrm{SO}_{4}$ & 16 & $584 \pm 5$ & $588 \pm 4$ & 11 & $581 \pm 4$ & $576 \pm 4$ \\
\hline $\mathrm{K}_{2} \mathrm{CrO}_{4}$ & 16 & $667 \pm 5$ & $673 \pm 4$ & 11 & $667 \pm 5$ & $661 \pm 6$ \\
\hline $\mathrm{BaCO}_{3}$ & 16 & $808 \pm 8$ & $819 \pm 6$ & 11 & $768 \pm 13$ & $750 \pm 15$ \\
\hline $\mathrm{SrCO}_{3}$ & $15 / 14$ & $930 \pm 6$ & $941 \pm 8$ & 12 & $902 \pm 10$ & $893 \pm 10$ \\
\hline
\end{tabular}


Table 9. Mean temperature results $\left({ }^{\circ} \mathrm{C}\right)$ for thermocouple placed geometrically midway between sample and reference

axially (Code 30 ).

\begin{tabular}{|c|c|c|c|c|c|c|}
\hline \multirow[b]{2}{*}{ Compound } & \multicolumn{3}{|c|}{ Heating } & \multicolumn{3}{|c|}{ Cooling } \\
\hline & $\underline{N}$ & Onset & Peak & $\underline{N}$ & Onset & Peak \\
\hline $\mathrm{KNO}_{3}$ & 4 & $129 \pm 4$ & $136 \pm 3$ & 2 & 124 & 120 \\
\hline In & 2 & 148 & 152 & - & -- & - - \\
\hline Sn & 2 & 224 & 229 & - & - - & -- \\
\hline $\mathrm{KClO}_{4}$ & 4 & $297 \pm 5$ & $305 \pm 6$ & 2 & 291 & 284 \\
\hline $\mathrm{Ag}_{2} \mathrm{SO}_{4}$ & 4 & $423 \pm 4$ & $431 \pm 3$ & 2 & 407 & 405 \\
\hline $\mathrm{SiO}_{2}$ & 4 & $568 \pm 1$ & $570 \pm 1$ & 2 & 569 & 567 \\
\hline $\mathrm{K}_{2} \mathrm{SO}_{4}$ & 4 & $579 \pm 2$ & $584 \pm 2$ & 2 & 581 & 577 \\
\hline $\mathrm{K}_{2} \mathrm{CrO}_{4}$ & 4 & $660 \pm 1$ & $666 \pm 1$ & 2 & 663 & 659 \\
\hline $\mathrm{BaCO}_{3}$ & 6 & $803 \pm 4$ & $815 \pm 8$ & - & -- & -- \\
\hline $\mathrm{SrCO}_{3}$ & 4 & $925 \pm 2$ & $935 \pm 7$ & - & -- & -- \\
\hline
\end{tabular}

equilibrium transition temperatures for 8 to 9 of the materials for which reliable equilibrium data exist. Position 30 gave onset temperatures ranging from +1 to $-9{ }^{\circ} \mathrm{C}$ of equilibrium values.

4. For the peak temperature, positions $00,03,21$ and 30 produced mean values averaging $+4{ }^{\circ} \mathrm{C}$ of equilibrium transition temperatures for all materials. Position 10 produced mean values averaging $+9{ }^{\circ} \mathrm{C}$ of these equilibrium values.

5. For no material is the effect of $T$-thermocouple placement such that the maximum and minimum extrapolated onset or peak temperatures differ by more than the sum of their respective standard deviations. 
Considering only data for the COOLING mode, evaluation is limited to positions 00,10 and 21 since only 2 data points were available for any material examined using positions 03 and 30 . With this further restriction, the following general comments may be made:

1. For the extrapolated onset temperature, position 21 generally produced the lowest mean values.

2. Cooling peak temperatures occurred at increasing values in the order of positions $21,10,00$, for 8 of the 10 materials in the SITP.

3. Because of marked supercooling noted in five $\left(\mathrm{Sn}, \mathrm{KClO}_{4}\right.$, $\mathrm{Ag}_{2} \mathrm{SO}_{4}, \mathrm{BaCO}_{3}$ and $\mathrm{SnCO}_{3}$ ) of the ten materials studied, it was not considered of value to examine the influence of $T$-thermocouple position upon the difference between measured and equilibrium thermodynamic temperatures in the cooling mode.

\section{Sample Holder Configuration}

Assessment of the effect of sample holder configuration has been complicated by the fact that certain investigators used different configurations for different materials. Sometimes this was necessitated by the design of the instrument or by the materials of construction; sometimes by a desire to optimize the configuration to the sample. This change in configuration is particularly true for the two melting point systems included in the SITP, illustrating the special problems to instrumentation imposed by such systems. Results from 7 of the 15 sample holder configurations have not been included in this report since they represent the work of only one investigator or because they have been employed by 2 investigators only in the case of one or two samples.

The major configurations employed are listed in Table 10 and further detailed in Tables 11-18, while those omitted from further consideration in this Section are: 011, 304, $305,422,505,615$, and 625 . 
In Table 10 the lower number of data points is always associated with results in the cooling mode.

Table 10. Major sample holder configurations reported.

\begin{tabular}{|c|c|c|c|}
\hline $\begin{array}{l}\text { Code } \\
\text { number } \\
\end{array}$ & $\begin{array}{c}\text { Number of } \\
\text { investigators }\end{array}$ & $\begin{array}{l}\text { Number of } \\
\text { data points }\end{array}$ & \\
\hline 002 & 2 & $2-6$ & $\begin{array}{l}\text { Cylindrical block, uncovered } \\
\text { cylindrical wells, one } \mathrm{R} \text { and } \\
\text { one } \mathrm{S} \text {, well diameter }<\text { depth. }\end{array}$ \\
\hline 012 & 2 & $2-3$ & $\begin{array}{l}\text { Cylindrical block, loosely cov } \\
\text { cylindrical wells, one } R \text { and } \\
\text { one } S \text {, well diameter }<\text { depth. }\end{array}$ \\
\hline 402 & $4-7$ & $3-14$ & $\begin{array}{l}\text { Shallow cup, uncovered, bottom } \\
\text { uniformly = wall. }\end{array}$ \\
\hline 502 & $3-4$ & $2-6$ & $\begin{array}{l}\text { Equal cup, uncovered, bottom } \\
\text { uniform1y = wal1. }\end{array}$ \\
\hline 602 & $5-8$ & $6-13$ & $\begin{array}{l}\text { Deep cup, uncovered, bottom } \\
\text { uniform1y thinner than < wall. }\end{array}$ \\
\hline 603 & 2 & $2-4$ & $\begin{array}{l}\text { Deep cup, uncovered, bottom } \\
\text { uniform1y = wall. }\end{array}$ \\
\hline 604 & $1-4$ & $2-10$ & $\begin{array}{l}\text { Deep cup, uncovered, bottom } \\
\text { uniformly = wall. }\end{array}$ \\
\hline 701 & 2 & $0-4$ & Capillary, loosely covered. \\
\hline
\end{tabular}

Initially restricting the data evaluation to the HEATING mode, and with the understanding that due to limited data, other influences (sample size, thermocouple placement, etc.) may have shifted some of the average values quite drastically, some general comments may be made:

1. For the onset temperature, configuration 012 and 602 produced lower mean values while configurations 002 and 603 produced higher mean values. Other configurations produced generally intermediate mean values.

2. For the peak temperature, configuration 602 produced 1 ower mean values and configuration 002 produced higher mean values. Other configurations produced generally intermediate mean values. 
Table 11. Mean temperature results $\left({ }^{\circ} \mathrm{C}\right)$ for sample holder: cylindrical block, uncovered cylindrical wells (Code 002).

\begin{tabular}{|c|c|c|c|c|c|c|c|}
\hline \multirow[b]{2}{*}{ Compound } & \multicolumn{4}{|c|}{ Heating } & \multicolumn{3}{|c|}{ Cooling } \\
\hline & $\underline{N}$ & Onset & Peak & & $\underline{N}$ & Onset & Peak \\
\hline $\mathrm{KNO}_{3}$ & 6 & $135 \pm 7$ & $147 \pm$ & 8 & 2 & 128 & 125 \\
\hline In & 2 & 161 & 170 & & - & -- & -- \\
\hline Sn & 2 & 239 & 253 & & - & -- & -- \\
\hline $\mathrm{KClO}_{4}$ & 6 & $306 \pm 3$ & $322 \pm$ & 10 & 2 & 294 & 289 \\
\hline $\mathrm{Ag}_{2} \mathrm{SO}_{4}$ & 4 & $432 \pm 5$ & $443 \pm$ & 10 & 2 & 401 & 410 \\
\hline $\mathrm{SiO}_{2}$ & 4 & $577 \pm 4$ & $582 \pm$ & 7 & 2 & 576 & 574 \\
\hline $\mathrm{K}_{2} \mathrm{SO}_{4}$ & 5 & $589 \pm 5$ & $600 \pm$ & 10 & 2 & 586 & 582 \\
\hline $\mathrm{K}_{2} \mathrm{CrO}_{4}$ & 6 & $672 \pm 5$ & $683 \pm$ & 9 & 2 & 669 & 666 \\
\hline $\mathrm{BaCO}_{3}$ & 6 & $809 \pm 9$ & $828 \pm$ & 12 & 2 & 761 & 738 \\
\hline $\mathrm{SrCO}_{3}$ & 4 & $930 \pm 4$ & $946 \pm$ & 15 & 2 & 900 & 903 \\
\hline
\end{tabular}

Table 12. Mean temperature results $\left({ }^{\circ} \mathrm{C}\right)$ for sample holder:

cylindrical block, loosely covered cylindrical we1ls (Code 012).

Heating

Compound

$\mathrm{KNO}_{3}$

In

Sn

$\mathrm{KC}_{4}$

$\mathrm{Ag}_{2} \mathrm{SO}_{4}$

$\mathrm{SiO}_{2}$

$\mathrm{K}_{2} \mathrm{SO}_{4}$

$\mathrm{K}_{2} \mathrm{CrO}_{4}$

$\mathrm{BaCO}_{3}$

$\mathrm{SrCO}_{3}$
Onset

130

139

$\underline{\text { Peak }}$

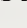

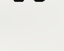

$-$

3

3

$299 \pm 4310 \pm 7$

$418 \pm 15428 \pm 20$

$570 \pm 5 \quad 574 \pm 4$

$577 \pm 14586 \pm 9$

$659 \pm 16669 \pm 11$

$800 \pm 12816 \pm 7$

$928 \pm 1941 \pm 2$
Cooling

\begin{tabular}{lcc}
\hline$N$ & Onset & Peak \\
\cline { 2 - 2 } 2 & 125 & 123 \\
- & -- & -- \\
- & -- & -- \\
2 & 289 & 284 \\
2 & 401 & 398 \\
2 & 575 & 572 \\
2 & 585 & 578 \\
2 & 670 & 662 \\
2 & 770 & 756 \\
2 & 900 & 899
\end{tabular}


Tab1e 13. Mean temperature results $\left({ }^{\circ} \mathrm{C}\right)$ for sample holder: shallow cup, uncovered (Code 402).

\begin{tabular}{|c|c|c|c|c|c|c|}
\hline \multirow[b]{2}{*}{ Compound } & \multicolumn{3}{|c|}{ Heating } & \multicolumn{3}{|c|}{ Cooling } \\
\hline & $\underline{\mathrm{N}}$ & Onset & Peak & $\underline{N}$ & Onset & Peak \\
\hline $\mathrm{KNO}_{3}$ & 13 & $129 \pm 2$ & $136 \pm 4$ & 6 & $122 \pm 1$ & $119 \pm 2$ \\
\hline In & 8 & $157 \pm 2$ & $161 \pm 3$ & $4 / 3$ & $154 \pm 1$ & $149 \pm 4$ \\
\hline $\mathrm{Sn}$ & 8 & $233 \pm 2$ & $238 \pm 4$ & 2 & 219 & 214 \\
\hline $\mathrm{KC} \mathrm{O}_{4}$ & 14 & $300 \pm 3$ & $308 \pm 4$ & 5 & $286 \pm 2$ & $282 \pm 3$ \\
\hline $\mathrm{Ag}_{2} \mathrm{SO}_{4}$ & 14 & $426 \pm 2$ & $434 \pm 4$ & 6 & $397 \pm 12$ & $395 \pm 11$ \\
\hline $\mathrm{SiO}_{2}$ & 14 & $571 \pm 2$ & $575 \pm 3$ & 6 & $572 \pm 4$ & $570 \pm 4$ \\
\hline $\mathrm{K}_{2} \mathrm{SO}_{4}$ & 14 & $581 \pm 3$ & $586 \pm 2$ & 6 & $582 \pm 6$ & $579 \pm 7$ \\
\hline $\mathrm{K}_{2} \mathrm{CrO}_{4}$ & 14 & $665 \pm 4$ & $671 \pm 3$ & 6 & $667 \pm 5$ & $663 \pm 6$ \\
\hline $\mathrm{BaCO}_{3}$ & 14 & $807 \pm 8$ & $817 \pm 4$ & 6 & $759 \pm 8$ & $743 \pm 9$ \\
\hline $\mathrm{SrCO}_{3}$ & 14 & $927 \pm 6$ & $935 \pm 4$ & $4 / 3$ & $902 \pm 11$ & $893 \pm 11$ \\
\hline
\end{tabular}

Table 14. Mean temperature results $\left({ }^{\circ} \mathrm{C}\right)$ for sampie holder: equal cup, uncovered (Code 502).

\begin{tabular}{|c|c|c|c|c|c|c|}
\hline \multirow[b]{2}{*}{ Compound } & \multicolumn{3}{|c|}{ Heating } & \multicolumn{3}{|c|}{ Cooling } \\
\hline & $\underline{N}$ & Onset & Peak & $\underline{N}$ & Onset & Peak \\
\hline $\mathrm{KNO}_{3}$ & 6 & $129 \pm 3$ & $135 \pm 4$ & 2 & 120 & 118 \\
\hline In & 6 & $155 \pm 4$ & $159 \pm 5$ & 2 & 152 & 150 \\
\hline $\mathrm{Sn}$ & 6 & $230 \pm 6$ & $237 \pm 6$ & 1 & 206 & -- \\
\hline $\mathrm{KClO}_{4}$ & $6 / 5$ & $299 \pm 5$ & $306 \pm 6$ & 2 & 285 & 281 \\
\hline $\mathrm{Ag}_{2} \mathrm{SO}_{4}$ & 6 & $424 \pm 5$ & $432 \pm 5$ & $2 / 1$ & 403 & 400 \\
\hline $\mathrm{SiO}_{2}$ & 6 & $573 \pm 1$ & $576 \pm 1$ & 2 & 569 & 567 \\
\hline $\mathrm{K}_{2} \mathrm{SO}_{4}$ & 6 & $584 \pm 2$ & $589 \pm 3$ & 2 & 581 & 576 \\
\hline $\mathrm{K}_{2} \mathrm{CrO}_{4}$ & 6 & $668 \pm 2$ & $673 \pm 3$ & 2 & 666 & 661 \\
\hline $\mathrm{BaCO}_{3}$ & 6 & $811 \pm 3$ & $819 \pm 2$ & 2 & 753 & 741 \\
\hline $\mathrm{SrCO}_{3}$ & $9 / 8$ & $936 \pm 8$ & $945 \pm 7$ & 5 & $920 \pm 22$ & $906 \pm 12$ \\
\hline
\end{tabular}


Table 15. Mean temperature results $\left({ }^{\circ} \mathrm{C}\right)$ for sample holder: deep cup, uncovered, bottom uniform1y = wall (Code 602).

\begin{tabular}{|c|c|c|c|c|c|c|c|c|c|c|}
\hline \multirow{3}{*}{$\frac{\text { Compound }}{\mathrm{KNO}_{3}}$} & \multicolumn{5}{|c|}{ Heating } & \multicolumn{5}{|c|}{ Cooling } \\
\hline & $\underline{N}$ & Onset & & Peak & & $\underline{N}$ & Onset & & Peak & \\
\hline & 10 & $124 \pm$ & 8 & $132 \pm$ & 5 & 6 & $124 \pm$ & 4 & $122 \pm$ & 3 \\
\hline In & $14 / 15$ & $154 \pm$ & 6 & $157 \pm$ & 7 & $6 / 5$ & $155 \pm$ & 2 & $153 \pm$ & 2 \\
\hline Sn & 14 & $230 \pm$ & 5 & $236 \pm$ & 6 & $6 / 4$ & $202 \pm$ & 8 & $215 \pm$ & 18 \\
\hline $\mathrm{KClO}_{4}$ & 12 & $294 \pm$ & 9 & $305 \pm$ & 5 & 6 & $290 \pm$ & 5 & $288 \pm$ & 5 \\
\hline $\mathrm{Ag}_{2} \mathrm{SO}_{4}$ & 12 & $419 \pm$ & 8 & $429 \pm$ & 7 & $6 / 5$ & $402 \pm$ & 4 & $405 \pm$ & 4 \\
\hline $\mathrm{SiO}_{2}$ & 13 & $566 \pm$ & 6 & $570 \pm$ & 5 & $6 / 8$ & $569 \pm$ & 2 & $569 \pm$ & 4 \\
\hline $\mathrm{K}_{2} \mathrm{SO}_{4}$ & 14 & $576 \pm$ & 8 & $584 \pm$ & 3 & $6 / 7$ & $582 \pm$ & 2 & $579 \pm$ & 3 \\
\hline $\mathrm{K}_{2} \mathrm{CrO}_{4}$ & 12 & $660 \pm$ & 6 & $668 \pm$ & 3 & 8 & $667 \pm$ & 5 & $662 \pm$ & 4 \\
\hline $\mathrm{BaCO}_{3}$ & 12 & $803 \pm$ & 7 & $815 \pm$ & 8 & 4 & $778 \pm$ & 11 & $768 \pm$ & 12 \\
\hline $\mathrm{SrCO}_{3}$ & 13 & $924 \pm$ & 5 & $932 \pm$ & 4 & 6 & $898 \pm$ & 9 & $901 \pm$ & 13 \\
\hline
\end{tabular}

Table 16. Mean temperature results $\left({ }^{\circ} \mathrm{C}\right)$ for sample holder: deep cup, uncovered, bottom non-uniformly = wall (Code 603).

\begin{tabular}{|c|c|c|c|c|c|c|c|}
\hline \multirow[b]{2}{*}{ Compound } & \multicolumn{4}{|c|}{ Heating } & \multicolumn{3}{|c|}{ Cooling } \\
\hline & $\underline{N}$ & Onset & Peak & & $\underline{N}$ & Onset & Peak \\
\hline $\mathrm{KNO}_{3}$ & 4 & $133 \pm 4$ & $141 \pm$ & 4 & 2 & 121 & 115 \\
\hline In & 4 & $159 \pm 3$ & $165 \pm$ & 1 & 2 & 154 & 148 \\
\hline $\mathrm{Sn}$ & 4 & $235 \pm 3$ & $243 \pm$ & 2 & 2 & 202 & 200 \\
\hline $\mathrm{KC} \mathrm{O}_{4}$ & 4 & $304 \pm 4$ & $313 \pm$ & 1 & 2 & 289 & 280 \\
\hline $\mathrm{Ag}_{2} \mathrm{SO}_{4}$ & 4 & $426 \pm 1$ & $437 \pm$ & 1 & 2 & 404 & 401 \\
\hline $\mathrm{SiO}_{2}$ & 4 & $576 \pm 3$ & $578 \pm$ & 5 & 2 & 574 & 571 \\
\hline $\mathrm{K}_{2} \mathrm{SO}_{4}$ & 4 & $590 \pm 6$ & $595 \pm$ & 5 & 2 & 585 & 579 \\
\hline $\mathrm{K}_{2} \mathrm{CrO}_{4}$ & 4 & $669 \pm 2$ & $678 \pm$ & 3 & 2 & 669 & 662 \\
\hline $\mathrm{BaCO}_{3}$ & 4 & $813 \pm 7$ & $824 \pm$ & 6 & 2 & 772 & 767 \\
\hline $\mathrm{SrCO}_{3}$ & 4 & $934 \pm 5$ & $944 \pm$ & 5 & 2 & 912 & 900 \\
\hline
\end{tabular}


Table 17. Mean temperature results $\left({ }^{\circ} \mathrm{C}\right)$ for sample holder:

deep cup, uncovered; bottom uniformly > wall (Code 604).

Compound

$\mathrm{KNO}_{3}$

In

$\mathrm{Sn}$

$\mathrm{KClO}_{4}$

$\mathrm{Ag}_{2} \mathrm{SO}_{4}$

$\mathrm{SiO}_{2}$

$\mathrm{K}_{2} \mathrm{SO}_{4}$

$\mathrm{K}_{2} \mathrm{CrO}_{4}$

$\mathrm{BaCO}_{3}$

$\mathrm{SrCO}_{3}$
Heating

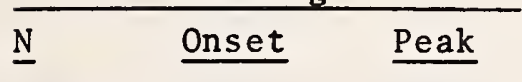

$8 \quad 126 \pm 4 \quad 131 \pm 2$

$10 \quad 154 \pm 7 \quad 160 \pm 5$

$10 \quad 231 \pm 5 \quad 237 \pm 4$

$8299 \pm 5 \quad 305 \pm 4$

9

7

8

8

10

8

$$
426 \pm 4 \quad 433 \pm 3
$$

$573 \pm 4 \quad 575 \pm 4$

$584 \pm 3 \quad 588 \pm 3$

$667 \pm 4 \quad 672 \pm 3$

$815 \pm 11823 \pm 11$

$933 \pm 6 \quad 942 \pm 7$
Cooling

\begin{tabular}{lcc}
\hline$\underline{N}$ & Onset & $\underline{\text { Peak }}$ \\
6 & $118 \pm 4$ & $116 \pm 4$ \\
7 & $154 \pm 5$ & $149 \pm 7$ \\
$6 / 4$ & $219 \pm 3$ & $215 \pm 6$ \\
6 & $286 \pm 1$ & $282 \pm 4$ \\
$5 / 4$ & $383 \pm 26$ & $378 \pm 28$ \\
5 & $571 \pm 2$ & $568 \pm 2$ \\
5 & $584 \pm 1$ & $579 \pm 1$ \\
5 & $670 \pm 3$ & $665 \pm 5$ \\
7 & $776 \pm 10$ & $763 \pm 9$ \\
5 & $902 \pm 15$ & $895 \pm 14$
\end{tabular}

Table 18. Mean temperature results $\left({ }^{\circ} \mathrm{C}\right)$ for sample holder: capillary, loosely covered (Code 701).

\begin{tabular}{|c|c|c|c|c|c|c|}
\hline \multirow[b]{2}{*}{ Compound } & & \\
\hline & $\underline{\mathrm{N}}$ & Onset & Peak & $\underline{N}$ & Onset & Peak \\
\hline $\mathrm{KNO}_{3}$ & 4 & $129 \pm 1$ & $130 \pm 1$ & 2 & 124 & 124 \\
\hline In & 2 & 157 & 158 & - & -- & -- \\
\hline $\mathrm{Sn}$ & - & -- & -- & - & -- & -- \\
\hline $\mathrm{KC} \mathrm{O}_{4}$ & 4 & $302 \pm 1$ & $303 \pm 3$ & 2 & 290 & 292 \\
\hline $\mathrm{Ag}_{2} \mathrm{SO}_{4}$ & 4 & $430 \pm 3$ & $434 \pm 2$ & 2 & 412 & 416 \\
\hline $\mathrm{SiO}_{2}$ & 3 & $577 \pm 2$ & $578 \pm 3$ & 1 & 576 & 575 \\
\hline $\mathrm{K}_{2} \mathrm{SO}_{4}$ & 3 & $589 \pm 3$ & $591 \pm 3$ & 1 & 587 & 587 \\
\hline $\mathrm{K}_{2} \mathrm{CrO}_{4}$ & 2 & 677 & 680 & - & -- & -- \\
\hline $\mathrm{BaCO}_{3}$ & 2 & 811 & 815 & - & -- & -- \\
\hline $\mathrm{SrCO}_{3}$ & - & -- & -- & - & -- & - \\
\hline
\end{tabular}


3. For the onset temperature, configurations 402, 503 and 604 produced mean values within $\pm 3{ }^{\circ} \mathrm{C}$ of the accepted equilibrium transition temperatures for at least eight of the nine materials for which reliable equilibrium data exist. Configurations 012 and 602 produced mean values generally lower than accepted equilibrium data, while configurations 002,603 and 701 produced generally higher mean values.

4. For the peak temperature, all configurations except 002 and 603 produced mean values within $+7{ }^{\circ} \mathrm{C}$ of the accepted equilibrium transition temperature for at least seven of the nine materials for which reliable equilibrium data exist. Configurations 002 and 603 produced mean peak temperatures averaging 12 to $17{ }^{\circ} \mathrm{C}$ above the equilibrium transition temperature.

5. Neglecting the possible effect of heating rate, the average difference between mean extrapolated onset and peak temperatures was 2 degrees for configuration 701 , and 11 to 12 degrees for configurations 002 and 012 . For all other configurations the difference was 7 to $8{ }^{\circ} \mathrm{C}$.

6. For most materials the effect of sample holder configuration is such that the maximum and minimum extrapolated onset or peak temperatures differ by an amount approximately equal to the sum of their respective standard deviations.

Considering only data for the COOLING mode, evaluation must be limited to configurations 402, 602 and 604 for which more than 2 data points were available. With this further restriction, the following general comments may be made:

1. For the onset temperature, configuration 402 tends to produce the higher mean values.

2. For the peak temperature no ranking could be made with respect to these three configurations.

3. For the extrapolated onset temperature all three configurations produced mean values averaging $14{ }^{\circ} \mathrm{C}$ below accepted equilibrium transition temperatures. 
4. For the peak temperatures all three configurations produced mean values averaging $14-20{ }^{\circ} \mathrm{C}$ below accepted equilibrium transition temperatures.

D. Resolution in the $4: 1: \mathrm{SiO}_{2}: \mathrm{K}_{2} \mathrm{SO}_{4}$ Mixture

The ability to obtain a measurable peak is occasionally more important than the ability to resolve close-lying thermal effects. More often, however, the ability to resolve two or more separate events is critical. To evaluate the resolution of the various types of apparatus, the investigators were asked to prepare a 4:1 mixture of silica and potassium sulfate. This composition gives two approximately equal peaks separated by about $11{ }^{\circ} \mathrm{C}$. Table 2 indicates that not all investigators were able to submit experimental data on the $4: 1$ mixture (by weight) of $\mathrm{SiO}_{2}$ and $\mathrm{K}_{2} \mathrm{SO}_{4}$. From the data obtained, there is no statistical difference in mean temperatures for either transition when compared with the corresponding temperature obtained when the compound was heated or cooled by itself. Thus, there was no influence of "dilution" by the other constituent.

To provide measures of the resolution of the two peaks, the concept of "base-1ine separation" (Figures $2 \mathrm{a}$ and $2 \mathrm{~b}$ ) was adopted arbitrarily. If $\mathrm{x}=$ the height of the $\mathrm{SiO}_{2}$ peak, $y=$ the minimum deviation of the experimental curve from the base-line in region between the peaks, then percent resolution $=\left[\begin{array}{ll}100 & \left(1-\frac{y}{x}\right)\end{array}\right]$.

As indicated by Table 19 approximately two thirds of the investigators reporting curves for the mixture achieved a resolution $\geq 90$ percent. The effect of construction $b$ is to raise the "percent resolution" above 100 percent in some cases due to accompanying base-1ine shifts. By construction $b$, a greater number, approximately three quarters of the investigators achieved a resolution $\geq 90$ percent. 


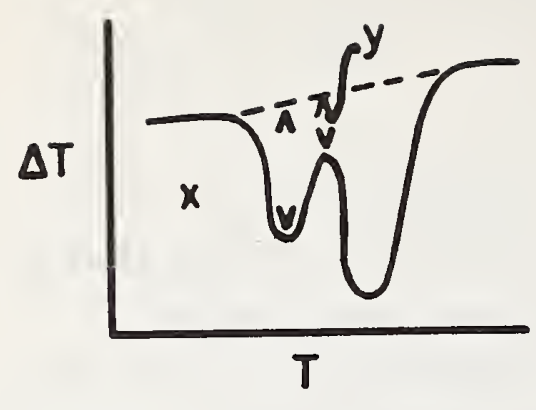

a

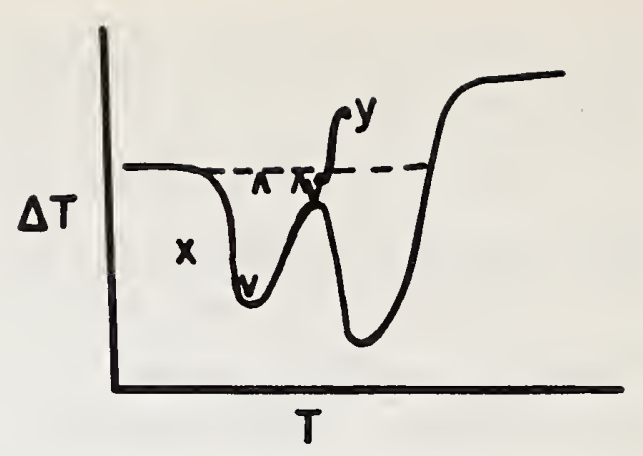

b

Figure 2. Peak resolution from base-1ine measurements (see a1so Table 19).

The purpose of any expression of peak resolution is to point out gross differences associated with sample holder configuration, heating rate, sample size and other parameters. In most cases, resolution $\leq 80$ percent by construction a was associated with sample sizes $\geq 200 \mathrm{mg}$ and/or heating rates of 10 to $12{ }^{\circ} \mathrm{C} \mathrm{min}^{-1}$. It is felt that the data are not sufficient to reject any particular sample holder configuration in terms of ability to resolve adjacent thermal affects. However, data in Table 19 do indicate that the $\mathrm{SiO}_{2}: \mathrm{K}_{2} \mathrm{SO}_{4}$ mixture is a suitable means for evaluating the ability of a particular combination of instrumental and experimental parameter to resolve two thermal effects occurring within $10^{\circ} \mathrm{C}$ of each other. 
Table 19. Peak resolution in $4: 1$ mixtures (by weight) of $\mathrm{SiO}_{2}$ and $\mathrm{K}_{2} \mathrm{SO}_{4}$.

Sample holder configuration

002

011

012

304

402

502

602

615

701
Sample weight (mg)

300

300

255

300

2.3

18

20

27

250

$-$

48.2

99.9

80

150

235

300

300

300

300

603

40.6

259.9

300

248.6

88.9

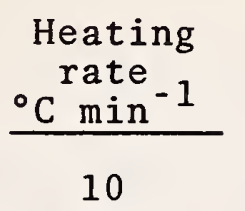

10.4

7.5

12

4.8

8

5.2

10

5.8

$--$

10

5.6

6.6

2

10

5

8

11

12

8

4.7

5

4.8

10
Percent resolution (average)

Fig. 2a Fig. 2b

93

104

83

87

96

76

100

91

100

94

92

100

76

93

98

90

79

97

91

33

56

88

97

67

77

98
78

100

101

100

98

96

100

87

92

115

101

79

114

128

41

95

115

114

64

91

108

\section{Distribution}

Investigators showing $\geq 95 \%$ Resolution 25

63

67

$"$ " $\quad \geq 80 \%$

71

75

83

\section{CONCLUSIONS}

Because approximately twice as many data were obtained in the heating mode as in the cooling mode, conclusions will be confined to the heating mode only. The present standards are not recommended for use in the cooling mode.

1. Over a group of 34 laboratories involving expert thermal analysts, no investigator showed an unacceptable 
systematic bias, as determined by the mean deviation being greater than $\pm 3 \sigma$ calculated over all compounds and all investigators. See also Figure 1.

2. None of these materials gave unusually precise or imprecise results. See Figure 3 .

3. On heating, the onset and peak temperatures can be used with virtually equal reliability $\left( \pm 6^{\circ} \mathrm{C}\right)$. The mean extrapolated onset temperature is closest to the reported equilibrium thermodynamic transition temperature (generally $-1{ }^{\circ} \mathrm{C}$ of this value).

4. No statistically significant deviation of individual results from the mean of all observations could be attributed to individual instrument parameters. This does not preclude the possibility of compensating effects within a given combination of parameters affecting one instrument. A trend to increasing differences between extrapolated onset and peak temperatures on heating was noted with increasing heating rate.

5. There is no statistically significant effect of $\mathrm{T}$-thermocouple calibration in the heating mode. The mean values for extrapolated onset and peak temperatures are consistently lower with calibrated thermocouples, but the difference is generally less than the smaller standard deviation.

6. Of the five T-thermocouple locations for which data exist from more than one investigator, position 30 generally corresponded with lowest mean onset and peak temperatures on heating. Other positions exerted a less consistent influence upon these mean values. For no material was the effect of $\mathrm{T}$-thermocouple location such that the maximum and minimum onset or peak temperatures differed by more than the sum of their respective. standard deviations.

7. Mean extrapolated onset temperatures for positions 00 , 03,10 and 21 , on heating, were within $\pm 3{ }^{\circ} \mathrm{C}$ of the 
accepted equilibrium transition temperatures for at least eight of the nine materials for which reliable equilibrium data exist.

8. Of the eight sample holder configurations for which essentially complete sets of data were available on heating from more than one investigator, configuration 602 produced generally low mean extrapolated onset and peak temperatures while configuration 002 produced generally high values. Other configurations exerted a less consistent influence upon these mean values. For most materials and configurations the difference between maximum and minimum extrapolated onset or peak temperatures was approximately equal to the sum of their respective standard deviations .

9. Mean extrapolated onset temperatures for configurations 402,502 and 604 were within $\pm 3^{\circ} \mathrm{C}$ of accepted equilibrium transition temperatures for at least eight of the nine materials for which reliable equilibrium data exist.

10. While both $\mathrm{T}$-thermocouple locations and sample holder configurations showed tendencies to influence the mean onset and peak temperatures on heating, the effect of these variables is not greater than the overall reproducibility $\left(+5\right.$ to $\left.9{ }^{\circ} \mathrm{C}\right)$ of the experimental data. The interaction of a number of instrumental parameters is suspected, however, the SITP data are not sufficient to permit a more detailed analysis.

11. The 4:1 mixture (by weight) of $\mathrm{SiO}_{2}$ and $\mathrm{K}_{2} \mathrm{SO}_{4}$ is a reasonable system for evaluating the ability of a given combination of instrumental parameters to resolve two thermal effects occurring about $10{ }^{\circ} \mathrm{C}$ apart. It will be desirable to have similar pairs of compounds which can be used to evaluate this resolution in other temperature ranges. 


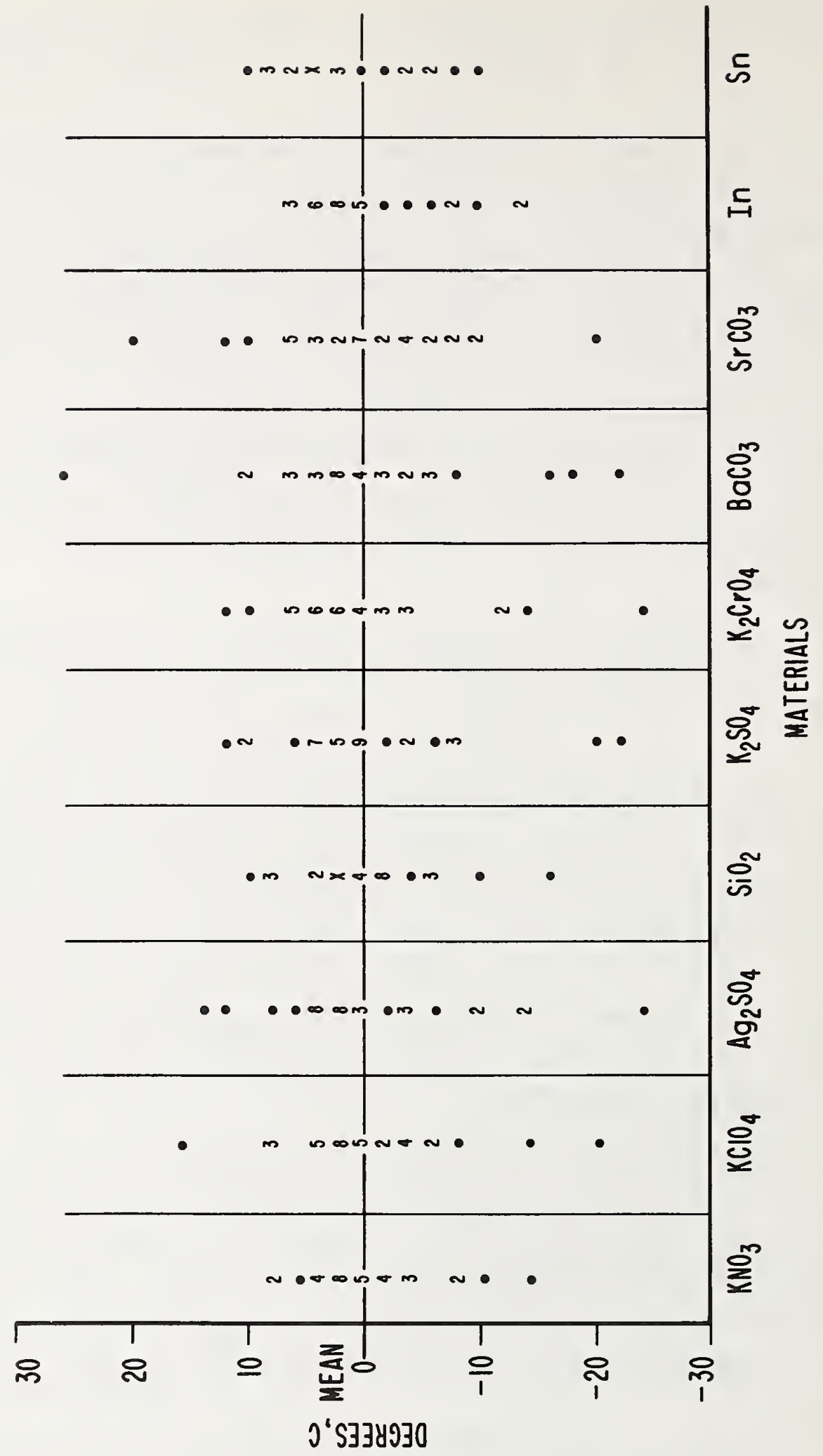

$n$
0
0
0
0
un
0
$\vdots$
in

0

$\stackrel{0}{\omega}$

432

$0<$

는

-

त)

(1) 1

$\rightarrow$ 담

0

414

is

\& 1

(

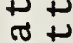

bo.

대 톨

u

(1)

? n

-

0

ह

-

$+\pi$

$\pi+$

(1)

(1)

0.

$u$

$\nabla+$

$\nabla$

딩

$0+$

it

41. त

통

证

旡 n

Q

m

(2)

ह

bo

is 
The material contained in this report represents the labors of 34 different laboratories, all of whom voluntarily contributed time and effort to participate in the SITP. The authors are grateful to them and their supporting organizations.

For the special support of one of us (H.G.M.) and his administration of the test program, the authors are grateful to the Ontario Research Foundation, and to Mrs. Jean Jervis who reviewed and encoded the data.

For the special support of one of us (P.D.G.) in his participation in the planning and the computation of data, the authors are grateful to the University of Akron and to R. Seaman who prepared the programs.

The authors further acknowledge the assistance of B.L. Joiner and H.H. Ku of the Applied Mathematics Division and J.T. Sterling and D.S. Bright of the Analytical Chemistry Division at NBS.

\section{REFERENCES}

[1] Youden, W. J., "Statistical Techniques for Collaborative Tests," Assocation of Official Analytical Chemists, Washington, D. C. (1967).

[2] NBS Circular 500, "Selective Values of Chemical Thermodynamic Properties" (1952).

[3] Hedva11, J. A., Lindner, R and Hartler, N., Acta Chem. Scand. 4 , 1099 (1950).

[4] NBS Technical Note 504. Superintendent of Documents, U. S. Government Printing Office, Washington, D. C. 20402

[5] Lander, J. J., J. Amer. Chem. Soc. 73, 5794 (1951). 

Revised Oct. 1-2, 1969

\section{PROCEDURES}

Second International Test Programme

DTA Temperature Standards

International Confederation for Thermal Analysis

Committee on Standardization

1. The operating conditions of each instrument should be those normally employed.

2. The accuracy of the temperature-measuring thermocouple should be known. If calibration is required the committee prefers use of recognized melting point standards.

3. All temperature data should be reported to the nearest $1{ }^{\circ} \mathrm{C}$.

4. A time-temperature curve from the temperature-measuring thermocouple should be included. If temperature is measured in the sample cell, this record should be obtained using aluminum oxide.

5. Each sample should be examined at one heating rate in the range of 4 to $10{ }^{\circ} \mathrm{Cmin}^{-1}$.

6. Both programmed heating and cooling should be employed if the apparatus permits. If cooling runs are made the rate of cooling should approximate the rate of heating.

7. The reference alumina supplied should be calcined to at least $1000{ }^{\circ} \mathrm{C}$ before use.

8. One curve of the reference material against the reference material should be supplied, using the maximum $\Delta \mathrm{T}$ sensitivity employed with the test materials. 
9. Samples should be used as received and not pre-treated in any way, except for potassium nitrate which should be cycled once to a temperature of 150 to $160{ }^{\circ} \mathrm{C}$ prior to making the reported runs.

10. Samples should not be diluted.

11. Maximum sample size should be approximately $300 \mathrm{mg}$.

12. At least two curves should be run on each material. If more than two curves are run and any rejected the rejected data should be forwarded with the other data together with the reason for rejection.

13. Conditions of packing of the sample within the sample holder should be specified.

14. The sample atmosphere should be oxygen-free nitrogen at 1 atm pressure dried over $\mathrm{MgClO}_{4}$ or its equivalent.

15. Where possible the same sample holder or container should be used for the entire series of tests.

16. The Committee would appreciate receiving a measurement of peak area as defined in the accompanying figure, expressed in the units ${ }^{\circ} \mathrm{C}^{2}$ per mg of sample. In this way instrument parameters such as $\Delta \mathrm{T}$ thermocouple material and response, amplifier sensitivity, chart speed, etc. can be reduced to a denominator common to all instruments.

17. Results should be reported according to the recommendations for good practice defined by the Committee.

18. The Committee would appreciate samples being examined in the randomized order provided to eliminate systematic bias.

19. Duplicate runs are also requested on a $4: 1 \quad \mathrm{SiO}_{2}: \mathrm{K}_{2} \mathrm{SO}_{4}$ mixture (by weight) using the silica and potassium sulphate provided. 


\section{INSTRUMENT DESCRIPTION}

Second International Test Programme

DTA Temperature Standards

\section{International Confederation for Thermal Analysis}

Committee on Standardization

\section{Investigator}

Instrument Manufacturer

Instrument Mode1 No.

$\Delta \mathrm{T}$ Thermocouple Material

$\Delta \mathrm{T}$ Thermocouple Wire Diameter (mm)

T-Thermocouple Material

T-Thermocouple Reference Temp $\left({ }^{\circ} \mathrm{C}\right)$

Was T-Thermocouple Calibrated? Yes . No. If yes, how?.

Location of $\mathrm{T}$-Thermocoup $1 \mathrm{e}$

Method of $\mathrm{T}$ Measurement

Sample Holder Material

Description of sample holder size and shape

Sample atmosphere flow pattern

Sample atmosphere flow rate $\left(\mathrm{cc} \min ^{-1}\right)$

Please supply a small drawing or photograph of the sample holder. 
0
0
0
-1
$\sim$
1
-1
+3
0
0
0
0
0
0
0
0
01

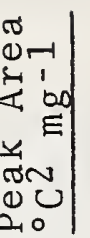

\begin{tabular}{ll|}
0 & \multirow{1}{*}{} \\
0 & 0 \\
0
\end{tabular} \mid

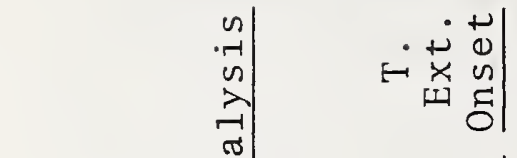

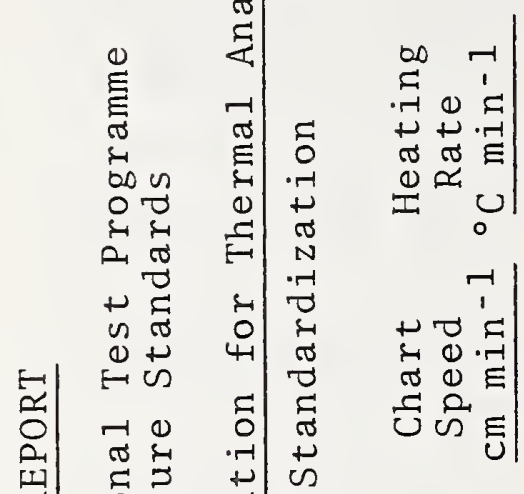

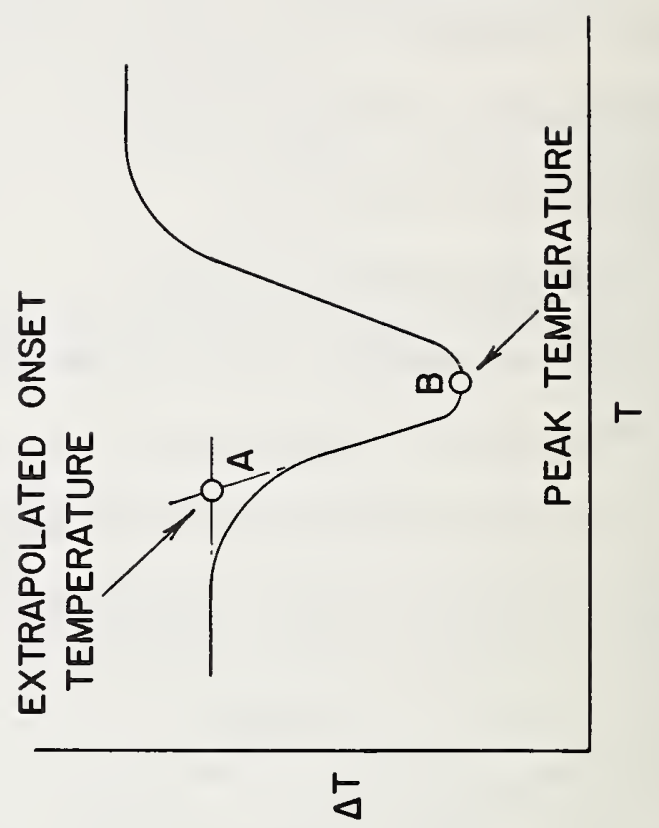

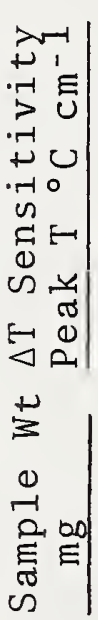

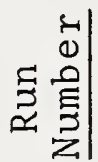

点| 
STANDARD METHOD OF CALIBRATION OF TEMPERATURE SCALE FOR DIFFERENTIAL THERMAL ANALYSIS

1. Scope

This test is for general use in differential thermal analysis. It provides means of relating temperatures of events observed in different laboratories and different instruments.

The test is applicable to a11 commercial and custombuilt apparatus. It can also be used for instruments classed as differential scanning calorimeters.

The purpose of this test is to determine the agreement in temperature under the specific conditions of the principal experiment, and not to determine the transition temperature of the Standard Reference Material. It is necessary to use the same sample holder assembly and heating rate in obtaining the peak(s) whose temperature(s) are to be related to other determinations.

2. Summary of Method

The method consists of obtaining the differential thermal analysis peak of one or more of the Standard Reference Materials under the normal operating conditions of the instrument, determining the extrapolated onset and peak temperatures, and comparing these temperatures with those established for the material. The difference provides a correction which is applied in relating data on test substances to data obtained on other instruments.

In correlating measurements, it will be necessary only to use NBS Standard Reference Materials whose peak temperatures are in the range of those of the test substance. However, use of Standard Reference Materials over the useful range of the instrument and at two or more heating rates will be an aid in determining the characteristics of the operator instrument. 
3. Significance

The differential thermal analysis peak results from many influences, some of which are characteristic of the sample holder assembly rather than the sample. The variations from instrument to instrument in the point of measurement of temperature and differential temperature, in sample size, in the kinds and composition of sample containers available with particular instruments and in accuracy of temperature scales all contribute to differences in measured temperatures which may exceed twenty degrees. In addition, some sample holder assemblies will show variations of measured temperature with sample size and/or heating rate. It is neither practical nor advisable to standardize sample holders. The alternative is the use of agreed-upon reference points and measurement of the deviation of the observed temperature from the reference temperature.

Small or large deviations should not be taken as a measure of the quality of an instrument. The temperatures assigned to the Standard Reference Materials are the means calculated from many experimental values obtained on a variety of instruments. Further information on variations may be obtained from the Committee on Standardization of the International Confederation for Thermal Analysis.

For sets of experiments performed on the same instrument in the same sample holder at the same heating rate, this test is generally unnecessary, but in relating data among instruments of the same type this calibration is desirable.

The use of this method at several heating rates will also be helpful in separating instrumental effects from effects arising within the sample.

4. Definitions of Terms and Abbreviations

This list includes definitions which agree with those adopted by the International Confederation for Thermal Analysis. 
Peak - that part of a DTA curve which is attributable to the occurrence of some single process. It normally is characterized by a deviation from the established base 1 ine, a maximum deflection, and re-establishment of a base line not necessarily identical to that before the peak.

Extrapolated Onset - empirically, the temperature found by extrapolating the base line (prior to the peak) and the leading side of the peak to their intersection. The section showing the closest approach to a straight line is taken. See Figure 2 .

Peak temperature - the temperature indicated at the time of the maximum value of the differential temperature during that peak.

Differential Thermal Analysis (DTA) - a technique of recording the difference in temperature (differential temperature) between a substance and a reference material against either time or temperature as the two specimens are subjected to identical temperature regimes in an environment heated or cooled at a controlled rate.

The record is the differential thermal or DTA curve; the temperature difference $(\Delta T)$ should be plotted on the ordinate with endothermic reactions downward and $\underline{t}$ or $\underline{T}$ on the abscissa increasing from left to right.

Test Substance - the material whose DTA curve is to be compared to the DTA curve obtained on another instrument.

5. Apparatus

The test is designed for all types of apparatus. Most of the Standard Reference Materials were selected for their solid $\stackrel{\leftarrow}{\rightarrow}$ solid transitions. These may be used in sample holder assemblies in which liquids cannot be used satisfactorily. For those sample holders which hold liquids satisfactorily, all of the Standard Reference Materials may be used. 
6. Standard Reference Materials

The temperature standards used in this method are the materials selected and tested during the second international test program by the International Confederation for Thermal Analysis. Except for indium and tin, each exhibits a solid $\stackrel{\leftrightarrow}{\rightarrow}$ solid transition which is well-defined and highly reproducible and has been characterized also by isothermal techniques. The materials are chemically stable and substantially inert.

The standards are being issued jointly by the International Confederation for Thermal Analysis and the National Bureau of Standards. The certified values are the means of values obtained by 34 laboratories. They are available in sets from the National Bureau of Standards, SRM 758, 759 and 760. Each set comprises five materials:

$\mathrm{SRM} 758-\mathrm{KNO}_{3}$, In (metal) Sn (metal), $\mathrm{KClO}_{4}, \mathrm{Ag}_{2} \mathrm{SO}_{4}$ temperature range: $128-430{ }^{\circ} \mathrm{C}$.

$\mathrm{SRM} 759-\mathrm{KClO}_{4}, \mathrm{Ag}_{2} \mathrm{SO}_{4}, \mathrm{SiO}_{2}, \mathrm{~K}_{2} \mathrm{SO}_{4}, \mathrm{~K}_{2} \mathrm{CrO}_{4}$ temperature range: $299-665^{\circ} \mathrm{C}$.

$\mathrm{SRM} 760-\mathrm{SiO}_{2}, \mathrm{~K}_{2} \mathrm{SO}_{4}, \mathrm{~K}_{2} \mathrm{CrO}_{4}, \mathrm{BaCO}_{3}, \mathrm{SrCO}_{3}$ temperature range: $573-925^{\circ} \mathrm{C}$.

7. Interferences

Potassium nitrate shows a dependence on previous history. The material should be heated to 150-160 degrees prior to standardizing.

The measurements should be made in an inert, dry atmosphere. This simulates conditions under which the values were established.

8. Procedure A

Place an amount of the selected Standard Reference Material, equivalent in weight to the test substance, in the same or similar type of sample holder as the test substance, and subject it to the same procedure as the test substance. 


\section{Procedure $B$}

This procedure is used to acquaint the operator with the characteristics of the instrument. It requires no formal report, only entry in the laboratory notebook; posting of correction near the instrument is also helpful.

A portion of the selected Standard Reference Material corresponding to typical samples is placed in the selected sample holder and subjected to the maximum heating rate. The specimen is cooled and subjected to the minimum heating rate. The extrapolated onset and peak temperatures are measured. If either of these values differs greatly with heating rate, sufficient intermediate heating rates are used to determine the behavior of the system. The differences between the measured values and the given values are calculated and tabulated.

A second Standard Reference Material is subjected to the same testing program. Sufficient Standard Reference Materials are run to tabulate corrections at each heating rate over the useful temperature range of the instrument and sample holder.

The procedure is repeated for other sample holder ass emblies.

10. Report

The report should include the following information:

(a) Appropriate information concerning the test substance and conditions of the measurement.

(b) The corrected extrapolated onset and peak temperature for each peak.

(c) Notation that the temperatures have been corrected using Standard Reference Materials. 

Certificates:

NBS - ICTA Standard Reference Materia1 759

DTA Temperature Standards (295-675 $\left.{ }^{\circ} \mathrm{C}\right)$

NBS - ICTA Standard Reference Materia1 758

DTA Temperature Standards (125-435 $\left.{ }^{\circ} \mathrm{C}\right)$

NBS - ICTA Standard Reference Material 760

DTA Temperature Standards (570-940 $\left.{ }^{\circ} \mathrm{C}\right)$ 



\section{NBS-ICTA Standard Reference Material 758 DTA Temperature Standards $\left(125-435^{\circ} \mathrm{C}\right)$}

These standards include: high-purity potassium nitrate, indium, tin, commercial grade potassium perchlorate, and analyzed reagent silver sulfate. They are for use in calibrating the temperature scale on differential thermal analysis and related thermoanalytical equipment under the operating conditions. They are to be used only in the heating mode.

\section{Transition Temperature Data $\left({ }^{\circ} \mathrm{C}\right)$}

\begin{tabular}{lccc} 
Material & $\begin{array}{c}\text { DTA Mean Values } \\
\text { Equilibrium } \\
\text { Value [1] }\end{array}$ & $\begin{array}{c}\text { Extrapolated } \\
\text { Onset }\end{array}$ & Peak \\
\cline { 2 - 2 } & 127.7 & 128 & 135 \\
$\mathrm{KNO}_{3}$ & 157 & 154 & 159 \\
In (metal) & 231.9 & 230 & 237 \\
$\mathrm{Sn}_{\mathrm{KClO}}$ & 299.5 & 299 & 309 \\
$\mathrm{Ag}_{2} \mathrm{SO}_{4}$ & - (a) & 424 & 433
\end{tabular}

(a)'The value for lhe Iransition temperature reported for this material [1] is currently under review. A more recent value of $430{ }^{\circ} \mathrm{C}$ has been reporled $\{2\}$.

For potassium nitrate only, the first heating of the material is not a reliable measure of the transition temperature. This sample must be cycled through the transition temperature in situ beforc recording data.

The extrapolated onset temperature is defined (Point A, Figure 1) as that temperature found by extrapolating the base line, prior to the peak, and the leading side of the peak to their intersection. The peak temperature (Point B, Figure 1) is defined as the temperature corresponding to the point of maximum deflection of the differential temperature curve.

Based on the mean value from 34 cooperating laboratories, the standard deviation was $5-8^{\circ} \mathrm{C}$, which includes the bias among laboratories as well as measurement errors. In the heating mode, onset and peak temperatures have about equal precision. However, the mean extrapolated onset temperatures are closer to the equilibrium transition temperatures. ICTA.

The materials for these standards were furnished by the Committee on Standardization of the

The International Test Program leading to the data on which certification is based was coordinated by H. G. McAdie, Chairman, ICTA Committce on Standardization.

Coordination of efforts leading to certification by NBS was under the chairmanship of $\mathrm{O}$. Menis.

The technical and support aspects involved in the preparation, certification, and issuance of thcsc Standard Reference Matcrials were coordinated through the Office of Standard Reference Materials by T. W. Mears.

Washington, D. C. 20234

June 11, 1971
J. Paul Cali, Chief

Office of Standard Reference Materials 
The transition temperatures given are the means of values obtained on 28 different types of commercial or custom-made instruments, and do not necessarily agree with the equilibrium values $[1,2]$. Generally, values from DTA are somewhat higher than the equilibrium values and vary in a complex manner for different instruments and heating rates. Details of the instruments used, the test conditions and complete data will be given in an NBS Special Publication in the 260 series (in publication).

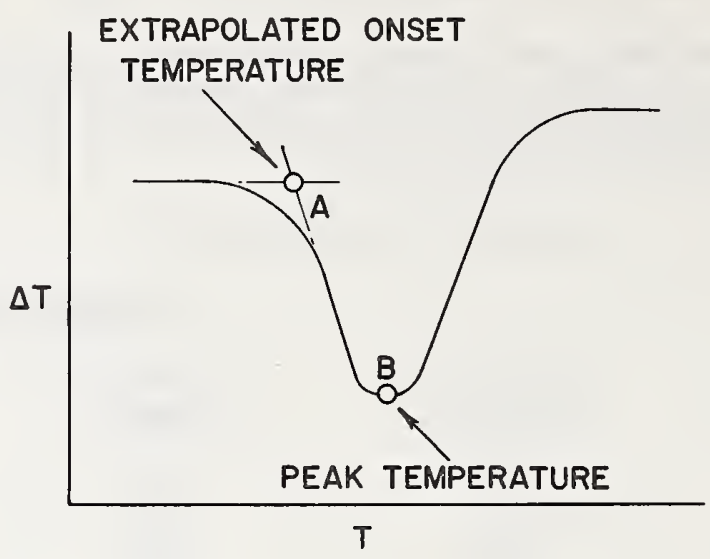

[1] Nat. Bur. Stand. (U.S.), Circ. 500 (1952).

[2] Hedvall, J. A., Lindner, R., and Hartler, N., Acta. Chem. Scand. 4, 1099 (1950). 
Dr. David E. Baum, Monsanto Australia Limited, West Footscray, Victoria, Australia Prof. Marcel Bourgon, Université de Montréal, Montréal, Quebec, Canada

Dr. H. G. McAdie, Ontario Research Foundation, Sheridan Park, Ontario, Canada

Dr. Klaus Heide, Friedrich-Schiller-Universität, Jena, Germany

Dr. J. Wiegmann, Berlin, Germany

Dr. G. R. Cizeron, Université de Paris, Paris, France

Dr. M. Harmelin, C.N.R.S., Paris, France

Mme. J. Jegoudez, Université de Paris, Paris, France

Dr. M. Foldvari, Hungarian Geological Institute, Budapest, Hungary

Mr. J. Paulik, Technical University of Budapest, Budapest, Hungary

Prof. H. Kambe, University of Tokyo, Tokyo, Japan

Prof. C. Kato, Waseda University, Tokyo, Japan

Prof. K. Oinuma, Tokyo University, Tokyo, Japan

Prof. R. Otsuka, Waseda University, Tokyo, Japan

Mr. J. E. Kruger, National Building Research Institute, Pretoria, South Africa

Dr. R. S. Forsyth, Aktiebolaget Atomenergi, Studsvik-Nyköping, Sweden

Dr. G. Krien, Institut für Chemisch-Techn. Untersuchungen, Leverkusen, Germany

Prof. H. R. Oswald, Universität Zurich, Zurich, Switzerland

Dr. T. Peters, Universität Berne, Berne, Switzerland

Dr. H. G. Wiedemann, Mettler Instrumentc A. G., Greifensee, Switzerland

Prof. L. G. Berg, Gosuniversitet, Kazan, U.S.S.R.

Prof. E. K. Koehler, Academy of Scicnces of the USSR, Novosibirsk, USSR

Dr. I. S. Rassonskaya, Institut Obshchei i Neorganicheskoi Khimii, Moscow, USSR

Dr. G. O. Piloyan, Academy of Sciences of the USSR, Moscow, USSR

Mr. E. L. Charsley, Stanton Redcroft Limitcd, London, England

Dr. R. C. Mackenzie, The Macaulay Institute for Soil Research, Aberdecn, Scotland 
Prof. D. A. Smith and Mr. J. Youren, Queen Mary College, Univerșity of London, London, England Dr. P. K. Gallagher, Bell Telephone Laboratories, Murray Hill, N.J., U.S.A.

Prof. P. D. Garn, University of Akron, Akron, Ohio, U.S.A.

Dr. O. Menis, D. S. Bright, and J. T. Sterling, National Bureau of Standards, Washington, D.C., U.S.A.

Mr. T. D. Oulton, Englehard Minerals \& Chemicals Corp., Edison, N.J.,U.S.A.

Dr. R. K. Ware, Owens-Illinois, Toledo, Ohio,U.S.A.

International Confederation for Thermal Analysis Committee on Standardization:

Chairman

Vice-Chairman

Secretary

National Delegates

Representative

Delegates

Ex-Officio

Delegates
(Canada)

(U.S.A.)

(U.K.)

(France)

(German D.R.)

(Hungary)

(Japan)

(Sweden)

(Switzerland)

(U.S.S.R.)

(U.K.)

(U.S.A.)

(U.S.A.)

(U.S.A.)

(U.K.)

(U.S.A.)

(U.S.S.R.)

(U.S.A.)

(U.K.)

(U.K.)
H. G. McAdie

P. D. Garn

R. C. Mackenzie

C. Mazieres

K. Heide

F. Paulik

H. Kambe

R. S. Forsyth

H. G. Wiedemann

I. S. Rassonskay a

D. A. Smith

R. W. Pfeil

Vacant

Vacant

O. Menis

C. J. Keattch

Vacant

L. G. Berg

C. B. Murphy

R. C. Mackenzie

J. P. Redfern 


\section{NBS-ICTA Standard Reference Material 759 DTA Temperature Standards $\left(295-675^{\circ} \mathrm{C}\right)$}

These standards include: analyzed reagent silver sulfate, potassium sulfate, potassium chromate; commercial grade potassium perchlorate; and natural quartz. They are for use in calibrating the temperature scale on differential thermal analysis and related thermoanalytical equipment under operating conditions. They are to be used only in the heating mode.

\section{Transition Temperature Data $\left({ }^{\circ} \mathrm{C}\right)$}

\begin{tabular}{lccc} 
Material & $\begin{array}{c}\text { Equilibrium } \\
\text { Value [1] }\end{array}$ & $\begin{array}{c}\text { DTA Mean Values } \\
\text { Extrapolated } \\
\text { Onset }\end{array}$ & Peak \\
\cline { 2 - 2 } & 299.5 & 299 & 309 \\
$\mathrm{KClO}_{4}$ & $-(\mathrm{a})$ & 424 & 433 \\
$\mathrm{Ag}_{2} \mathrm{SO}_{4}$ & 573 & 571 & 574 \\
$\mathrm{SiO}_{2}$ & 583 & 582 & 588 \\
$\mathrm{~K}_{2} \mathrm{SO}_{4}$ & 665 & 665 & 673 \\
$\mathrm{~K}_{2} \mathrm{CrO}_{4}$ & & &
\end{tabular}

(a) The value for the transition temperature reported for this material [1] is currently under review. A more recent value of $430{ }^{\circ} \mathrm{C}$ has been reported [2].

The extrapolated onset temperature is defined (Point A, Figure 1 ) as that temperature found by extrapolating the base line, prior to the peak, and the leading side of the peak to their intersection. The peak temperature (Point B, Figure I) is defined as the temperature corresponding to the point of maximum deflection of the differential temperature curve.

Based on the mean value from 34 cooperating laboratories, the standard deviation was $5 \cdot 8^{\circ} \mathrm{C}$, which includes the bias among laboratories as well as mcasurement errors. In the heating mode, onset and peak temperatures have about equal precision. However, the mean extrapolated onset temperatures are closer to the equilibrium transition temperatures. ICTA.

The materials for these standards were furnished by the Committee on Standardization of the

The International Test Program leading to the data on which certification is based was coordinated by H. G. McAdie, Chairman, ICTA Committee on Standardization.

Coordination of efforts leading to certification by NBS was under the chairmanship of O. Menis.

The technical and support aspects involved in thc preparation, certification, and issuance of these Standard Referencc Materials were coordinated through the Office of Standard Reference Materials by T. W. Mears.

Washington, D. C. 20234

June 11, 1971

\section{J. Paul Cali, Chief}

Office of Standard Reference Materials 
The transition temperatures given are the means of values obtained on 28 differcnt types of commercial or custom-made instruments, and do not necessarily agree with the equilibrium values $[1,2]$. Generally, values from DTA are somewhat higher than the equilibrium values and vary in a complex manner for different instruments and heating rates. Details of the instruments used, the test conditions and complete data will be given in an NBS Special Publication in the 260 series (in publication).

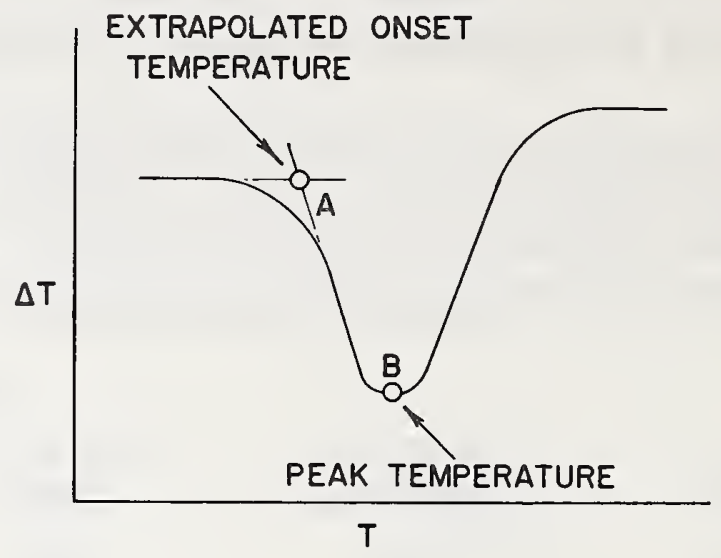

[1] Nat. Bur. Stand. (U.S.), Circ. 500 (1952).

[2] Hedvall, J. A., Lindner, R., and Hartler, N., Acta. Chem. Scand. 4, 1099 (1950). 
Dr. David E. Baum, Monsanto Australia Limited, West Footscray, Victoria, Australia Prof. Marcel Bourgon, Université de Montréal, Montréal, Quebec, Canada

Dr. H. G. McAdie, Ontario Research Foundation, Sheridan Park, Ontario, Canada

Dr. Klaus Heide, Friedrich-Schiller-Universität, Jena, Germany

Dr. J. Wiegmann, Berlin, Germany

Dr. G. R. Cizeron, Université de Paris, Paris, France

Dr. M. Harmelin, C.N.R.S., Paris, France

Mme. J. Jegoudez, Université de Paris, Paris, France

Dr. M. Foldvari, Hungarian Geological Institute, Budapest, Hungary

Mr. J. Paulik, Technical University of Budapest, Budapest, Hungary

Prof. H. Kambe, University of Tokyo, Tokyo, Japan

Prof. C. Kato, Waseda University, Tokyo, Japan

Prof. K. Oinuma, Tokyo University, Tokyo, Japan

Prof. R. Otsuka, Waseda University, Tokyo, Japan

Mr. J. E. Kruger, National Building Research Institute, Pretoria, South Africa

Dr. R.S. Forsyth, Aktiebolaget Atomenergi, Studsvik-Nyköping, Sweden

Dr. G. Krien, Institut für Chemisch-Techn. Untersuchungen, Leverkusen, Germany

Prof. H. R. Oswald, Universität Zurich, Zurich, Switzerland

Dr. T. Peters, Universität Berne, Berne, Switzerland

Dr. H. G. Wiedemann, Mettler Instrumente A. G., Greifensee, Switzerland

Prof. L. G. Berg, Gosuniversitet, Kazan, U.S.S.R.

Prof. E. K. Koehler, Academy of Sciences of the USSR, Novosibirsk, USSR

Dr. I. S. Rassonskaya, Institut Obshchei i Neorganicheskoi Khimii, Moscow, USSR

Dr. G. O. Piloyan, Academy of Sciences of the USSR, Moscow, USSR

Mr. E. L. Charsley, Stanton Redcroft Limited, London, England

Dr. R. C. Mackenzie, The Macaulay Institute for Soil Research, Aberdeen, Scotland 
Prof. D. A. Smith and Mr. J. Youren, Queen Mary College, University of London, London, England Dr. P. K. Gallagher, Bell Telephone Laboratories, Murray Hill, N.J.,U.S.A.

Prof. P. D. Garn, University of Akron, Akron, Ohio, U.S.A.

Dr. O. Menis, D. S. Bright, and J. T. Sterling, National Bureau of Standards, Washington, D.C., U.S.A.

Mr. T. D. Oulton, Englehard Minerals \& Chemicals Corp., Edison, N.J.,U.S.A.

Dr. R. K. Ware, Owens-Illinois, Toledo, Ohio, U.S.A.

International Confederation for Thermal Analysis Committee on Standardization:

Chairman

Vice-Chairman

Secretary

National Delegates

Ex-Officio

Delegates

Representative
Delegates
(Canada)

(U.S.A.)

(U.K.)

(France)

(German D.R.)

(Hungary)

(Japan)

(Sweden)

(Switzerland)

(U.S.S.R.)

(U.K.)

(U.S.A.)

(U.S.A.)

(U.S.A.)

(U.K.)

(U.S.A.)

(U.S.S.R.)

(U.S.A.)

(U.K.)

(U.K.)
H. G. McAdie

P. D. Garn

R. C. Mackenzie

C. Mazieres

K. Hcide

F. Paulik

H. Kambe

R. S. Forsyth

H. G. Wiedemann

I. S. Rassonskaya

D. A. Smith

R. W. Pfeil

V acant

Vacant

O. Menis

C. J. Keattch

Vacant

L. G. Berg

C. B. Murphy

R. C. Mackenzie

J. P. Redfern 


\section{Uertifieate}

\section{NBS-ICTA Standard Reference Material 760}

\section{DTA Temperature Standards $\quad\left(570-940^{\circ} \mathrm{C}\right)$}

These standards include: natural quartz; analyzed reagent potassium sulfate, potassium chromate, barium carbonate, and strontium carbonate. They are for use in calibrating the temperature scale on differential thermal analysis and related thermoanalytical equipment under operating conditions. They are to be used only in the heating mode.

Transition Temperature Data $\left({ }^{\circ} \mathrm{C}\right)$

\begin{tabular}{lccc} 
Material & $\begin{array}{c}\text { Equilibrium } \\
\text { Value [1] }\end{array}$ & $\begin{array}{c}\text { ExA Mean Values } \\
\text { Enset }\end{array}$ & Peak \\
\cline { 2 - 3 } $\mathrm{SiO}_{2}$ & 573 & 571 & 574 \\
$\mathrm{~K}_{2} \mathrm{SO}_{4}$ & 583 & 582 & 588 \\
$\mathrm{~K}_{2} \mathrm{CrO}_{4}$ & 665 & 665 & 673 \\
$\mathrm{BaCO}_{3}$ & 810 & 808 & 819 \\
$\mathrm{SrCO}_{3}$ & 925 & 928 & 938
\end{tabular}

The extrapolated onset temperature is defined (Point A, Figure 1) as that temperature found by extrapolating the base line, prior to the peak, and the leading side of the peak to their intersection. The peak temperature (Point B, Figure 1) is defined as the temperature corresponding to the point of maximum deflection of the differential temperature curve.

Based on the mean value from 34 cooperating laboratories, the standard deviation was $5-8{ }^{\circ} \mathrm{C}$, which includes the bias among laboratories as well as measurement errors. In the heating mode, onset and peak temperatures have about equal precision. However, the mean extrapolated onset temperatures are closer to the equilibrium transition temperatures.

The materials for these standards were furnished by the Committee on Standardization of the ICTA.

The International Test Program leading to the data on which certification is based was coordinated by H. G. McAdie, Chairman, ICTA Committee on Standardization.

Coordination of efforts leading to certification by NBS was under the chairmanship of O. Menis.

The technical and support aspects involved in the preparation, certification, and issuance of these Standard Reference Materials were coordinated through the Office of Standard Reference Materials by T. W. Mears.

Washington, D. C. 20234

June 11, 1971
J. Paul Cali, Chief

Officc of Standard Reference Materials 
The transition temperatures given are the means of values obtained on 28 different types of commercial or custom-made instruments, and do not necessarily agree with the equilibrium values [1]. Generally, values from DTA are somewhat higher than the equilibrium values and vary in a complex manner for different instruments and heating rates. Details of the instruments used, the test conditions and complete data will be given in an NBS Special Publication in the 260 series (in publication).

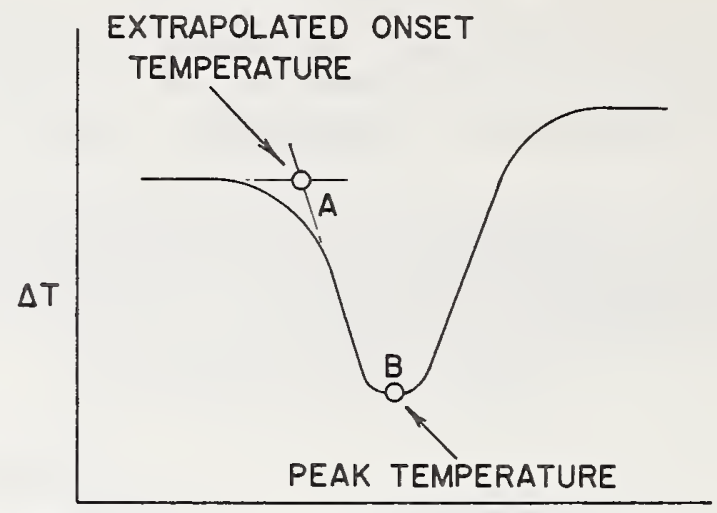

T

[1] Nat. Bur. Stand. (U.S.), Circ. 500 (1952). 
Dr. David E. Baum, Monsanto Australia Limited, West Footscray, Victoria, Australia Prof. Marcel Bourgon, Université de Montréal, Montréal, Quebec, Canada

Dr. H. G. McAdie, Ontario Research Foundation, Sheridan Park, Ontario, Canada

Dr. Klaus Heide, Friedrich-Schiller-Universität, Jena, Germany

Dr. J. Wiegmann, Berlin, Germany

Dr. G. R. Cizeron, Université de Paris, Paris, France

Dr. M. Harmelin, C.N.R.S., Paris, France

Mme. J. Jegoudez, Université de Paris, Paris, France

Dr. M. Foldvari, Hungarian Geological Institute, Budapest, Hungary

Mr. J. Paulik, Technical University of Budapest, Budapest, Hungary

Prof. H. Kambe, University of Tokyo, Tokyo, Japan

Prof. C. Kato, Waseda University, Tokyo, Japan

Prof. K. Oinuma, Tokyo University, Tokyo, Japan

Prof. R. Otsuka, Waseda University, Tokyo, Japan

Mr. J. E. Kruger, National Building Research Institute, Pretoria, South Africa

Dr. R. S. Forsyth, Aktiebolaget Atomenergi, Studsvik-Nyköping, Sweden

Dr. G. Krien, Institut für Chemisch-Techn. Untersuchungen, Leverkusen, Germany

Prof. H. R. Oswald, Universität Zurich, Zurich, Switzerland

Dr. T. Peters, Universität Berne, Berne, Switzerland

Dr. H. G. Wiedemann, Mettler Instrumente A. G., Greifensee, Switzerland

Prof. L. G. Berg, Gosuniversitet, Kazan, U.S.S.R.

Prof. E. K. Koehlcr, Academy of Sciences of the USSR, Novosibirsk, USSR

Dr. I. S. Rassonskaya, Institut Obshchei i Neorganicheskoi Khimii, Moscow, USSR

Dr. G. O. Piloyan, Academy of Sciences of the USSR, Moscow, USSR

Mr. E. L. Charsley, Stanton Rederoft Limited, London, England

Dr. R. C. Mackenzie, The Macaulay Institute for Soil Research, Aberdeen, Scotland 
Prof. D. A. Smith and Mr. J. Youren, Queen Mary College, University of London, London, England Dr. P. K. Gallagher, Bell Telephone Laboratories, Murray Hill, N.J., U.S.A.

Prof. P. D. Garn, University of Akron, Akron, Ohio, U.S.A.

Dr. O. Menis, D. S. Bright, and J. T. Sterling, National Bureau of Standards, Washington, D.C., U.S.A.

Mr. T. D. Oulton, Englehard Minerals \& Chemicals Corp., Edison, N.J.,U.S.A.

Dr. R. K. Ware, Owens-Illinois, Toledo, Ohio, U.S.A.

International Confederation for Thermal Analysis Committee on Standardization:

Chairman
Vice-Chairman
Secretary
National Delegates

Representative

Delegates

Ex-Officio

Delegates

(Canada)
(U.S.A.)
(U.K.)
(France)
(German D.R.)
(Hungary)
(Japan)
(Sweden)
(Switzerland)
(U.S.S.R.)
(U.K.)
(U.S.A.)
(U.S.A.)
(U.S.A.)
(U.K.)
(U.S.A.)
(U.S.S.R.)
(U.S.A.)
(U.K.)
(U.K.)

H. G. McAdie

P. D. Garn

R. C. Mackenzie

C. Mazieres

K. Hcide

F. Paulik

H. Kambe

R. S. Forsyth

H. G. Wiedemann

I. S. R assonskaya

D. A. Smith

R. W. Pfeil

ASTM

ISO

NBS

Soc.Anal.Chem.

SAMA

ICTA

(U.K.)

Vacant
Vacant
O. Menis
C. J. Keattch
Vacant
L. G. Berg
C. B. Murphy
R. C. Mackenzie
J. P. Redfern

V acant

Vacant

C. J. Keattch

L. G. Berg

R. C. Mackenzie

J. P. Redfern 


\begin{tabular}{|c|c|c|c|}
\hline $\begin{array}{l}\text { U.S. DEPT. OF COMM. } \\
\text { BIBLIOGRAPHIC DATA } \\
\text { SHEET }\end{array}$ & $\begin{array}{l}\text { 1. PUBLICATION OR REPORT NO. } \\
\text { NBS SP } 260-40\end{array}$ & $\begin{array}{l}\text { 2. Gov't Accession } \\
\text { No. }\end{array}$ & 3. Recipient's Accession No. \\
\hline \multirow{2}{*}{\multicolumn{3}{|c|}{$\begin{array}{l}\text { 4. TITLE AND SUBTITLE St andard Reference Materials: } \\
\text { SELECTION OF DIFFERENT IAL THERMAL ANALYSIS TEMPER- } \\
\text { ATURE STANDARDS THROUGH A COOPERATIVE STUDY, (SRM } \\
758,759,760)\end{array}$}} & $\begin{array}{l}\text { 5. Publication Date } \\
\text { August } 1972\end{array}$ \\
\hline & & & 6. Performing Organization Code \\
\hline \multicolumn{3}{|c|}{ 7. AUTHOR(S) H. G. McAdie, P. D. Garn, O. Menis } & 8. Performing Organization \\
\hline \multirow{2}{*}{\multicolumn{3}{|c|}{$\begin{array}{l}\text { 9. PERF ORMING ORGANIZATION NAME AND ADDRESS } \\
\qquad \begin{array}{l}\text { NATIONAL BUREAU OF STANDARDS } \\
\text { DEPARTMENT OF COMMERCE } \\
\text { WASHINGTON, D.C. } 20234\end{array}\end{array}$}} & 10. Project/Task/Work Unit No. \\
\hline & & & 11. Contract/Grant No. \\
\hline \multirow{2}{*}{\multicolumn{3}{|c|}{ 12. Sponsoring Organization Name and Address }} & $\begin{array}{l}\text { 13. Type of Report \& Period } \\
\text { Covered } \\
\text { Final }\end{array}$ \\
\hline & & & 14. Sponsoring Agency Code \\
\hline
\end{tabular}

15. SUPPLEMENTARY NOTES

16. ABSTRACT (A 200-word or less factual summary of most significant information. If document includes a significant bibliography or literature survey, mention it here.The testing and evaluation program leading to the certification of 10 materials as Standard Reference Materials NBS 758,759 and 760 , for calibrating the temperature scale for thermal analysis is described. The international cooperative testing program was set up on the basis of a preliminary program initiated in 1966. Thirty-four laboratories reported to the Standards Committee of the International Confederation on Thermal Analysis. The results were obtained on a variety of apparatus under their conditions of experimentation, except that the heating rate was prescribed in the range of 4 to $10{ }^{\circ} \mathrm{C}$ per minute. The data were processed to obtain means and measures of scatter, not oniy in total, but separated in terms of a number of sample number of sample holder parameters. The sample holder geometry was the only parameter having a clear effect on the extrapolated onset and peak temperatures. The effects of thermocouple position and calibration were tested, but no significant effect was found. The heating rate has only a smali effect, tending to increase the spread of onset and peak temperature values from the DTA are somewhat higher than the thermodynamic equilibrium values reported in the literature. Based on the mean values from all the laboratories the standard deviation was 5 to $8{ }^{\circ} \mathrm{C}$, which includes the bias between laboratories as we11 as measurement errors.

17. KEY WORDS (Alphabetical order, separated by semicolons) DTA; International Confederation on Thermal Analysis; international cooperative testing; Standard Reference Materials NBS 758,759, 760; temperature scale; thermal analysis.

\begin{tabular}{|c|c|c|}
\hline $\begin{array}{l}\text { 18. AVAILABILITY STATEMENT } \\
X \text { UNL IMIT ED. }\end{array}$ & $\begin{array}{l}\text { 19. SECURITY CLASS } \\
\text { (THIS REPORT) } \\
\text { UNCL ASSIFIED }\end{array}$ & $\begin{array}{l}\text { 21. NO. OF PAGES } \\
71\end{array}$ \\
\hline $\begin{array}{l}\square \text { FOR OFFICIAL DIST RIBUTION. DO NOT RELEASE } \\
\text { TO NTIS. }\end{array}$ & $\begin{array}{l}\text { 20. SECURITY CLASS } \\
\text { (THIS PAGE) } \\
\text { UNCL ASSIFIED }\end{array}$ & $\begin{array}{l}\text { 22. Price } \\
65 \text { cents }\end{array}$ \\
\hline
\end{tabular}



PERIODICALS

JOURNAL OF RESEARCH reports National Bureau of Standards research and development in physics, mathematics, and chemistry. Comprehensive scientific papers give complete details of the work, including laboratory data, experimental procedures, and theoretical and mathematical analyses. Illustrated with photographs, drawings, and charts. Includes listings of other NBS papers as issued.

Published in two sections, available separately:

\section{- Physics and Chemistry}

Papers of interest primarily to scientists working in these fields. This section covers a broad range of physical and chemical research, with major emphasis on standards of physical measurement, fundamental constants, and properties of matter. Issued six times a year. Annual subscription: Domestic, $\$ 9.50 ; \$ 2.25$ additional for foreign mailing.

\section{- Mathematical Sciences}

Studies and compilations designed mainly for the mathematician and theoretical physicist. Topics in mathematical statistics, theory of experiment design, numerical analysis, theoretical physics and chemistry, logical design and programming of computers and computer systems. Short numerical tables. Issued quarterly. Annual subscription: Domestic, \$5.00; $\$ 1.25$ additional for foreign mailing.

\section{TECHNICAL NEWS BULLETIN}

The best single source of information concerning the Bureau's measurement, research, developmental, cooperative, and publication activities, this monthly publication is designed for the industry-oriented individual whose daily work involves intimate contact with science and technology-for engineers, chemists, physicists, research managers, product-development managers, and company executives. Includes listing of all NBS papers as issued. Annual subscription: Domestic, $\$ 3.00 ; \$ 1.00$ additional for foreign mailing.

\section{Bibliographic Subscription Services}

The following current-awareness and literaturesurvey bibliographies are issued periodically by the Bureau: Cryogenic Data Center Current Awareness Service (weekly), Liquefied Natural Gas (quarterly), Superconducting Devices and Materials (quarterly), and Electromagnetic Metrology Current Awareness Service (monthly). Available only from NBS Boulder Laboratories. Ordering and cost information may be obtained from the Program Information Office, National Bureau of Standards, Boulder, Colorado 80302 .

\section{NONPERIODICALS}

Applied Mathematics Series. Mathematical tables, manuals, and studies.

Building Science Series. Research results, test methods, and performance criteria of building materials, components, systems, and structures.

Handbooks. Recommended codes of engineering and industrial practice (including safety codes) developed in cooperation with interested industries, professional organizations, and regulatory bodies.

Special Publications. Proceedings of NBS conferences, bibliographies, annual reports, wall charts, pamphlets, etc.

Monographs. Major contributions to the technical literature on various subjects related to the Bureau's scientific and technical activities.

National Standard Reference Data Series. NSRDS provides quantitative data on the physical and chemical properties of materials, compiled from the world's literature and critically evaluated.

Product Standards. Provide requirements for sizes, types, quality, and methods for testing various industrial products. These standards are developed cooperatively with interested Government and industry groups and provide the basis for common understanding of product characteristics for both buyers and sellers. Their use is voluntary.

Technical Notes. This series consists of communications and reports (covering both other-agency and NBS-sponsored work) of limited or transitory interest.

Federal Information Processing Standards Publications. This series is the official publication within the Federal Government for information on standards adopted and promulgated under the Public Law 89-306, and Bureau of the Budget Circular A-86 entitled, Standardization of Data Elements and Codes in Data Systems.

Consumer Information Series. Practical information, based on NBS research and experience, covering areas of interest to the consumer. Easily understandable language and illustrations provide useful background knowledge for shopping in today's technological marketplace.

\section{CATALOGS OF NBS PUBLICATIONS}

NBS Special Publication 305, Publications of the NBS. 1966-1967. When ordering, include Catalog No. C13.10:305. Price $\$ 2.00 ; 50$ cents additional for foreign mailing.

NBS Special Publication 305, Supplement 1, Publications of the NBS, 1968-1969. When ordering, include Catalog No. C13.10:305/Suppl. 1. Price $\$ 4.50 ; \$ 1.25$ additional for foreign mailing.

NBS Special Publication 305, Supplement 2, Publications of the NBS, 1970. When ordering, include Catalog No. C13.10:305/Suppl. 2. Price $\$ 3.25 ; 85$ cents additional for foreign mailing.

Order NBS publications (except Bibliographic Subscription Services) from: Superintendent of Documents, Government Printing Office, Washington, D.C. 20402. 
U.S. DEPARTMENT OF COMMERCE

National Bureau of Standards

Washington, D.C. 20234

OFFICIAL BUSINESS

Penalty for Private Use, $\$ 300$
PDSTAGE AND FEES PAID U.S. DEPARTMENT OF CDMMERCE 215 